\title{
LA IRONÍA DEL POSITIVISMO JURÍDICO
}

\author{
F. Atria \\ Universidad de Talca, Chile
}

RESUMEN. Este artículo discute la actual disputa familiar entre los llamados positivistas "blandos" y "duros". Se sostiene que esta disputa muestra que el positivismo jurídico contemporáneo ha rechazado el importante y original enfoque que le identificaba originariamente. El positivismo jurídico nació como una teoría del Derecho moderno, una forma de Derecho que era artificial y contingentemente construido, más que descubierto a través del uso de la razón. El estado actual de la teoría y práctica jurídica muestra la necesidad de volver a esta versión "ética” del positivismo jurídico, porque estamos asistiendo a un tipo de involución jurídica hacia formas jurídicas premodernas que suelen denominarse "neo-constitucionalismo"; una involución que -si el enfoque del positivismo jurídico original es todavía válido, tal como este artículo defiendedebe resistirse. Tal teoría "ética" fuerte debe entender a la legislación como el non plus ultra del Derecho, y a los jueces como sometidos al legislador, sin reducir la aplicación a una actividad mecánica.
Abstract. This article discusses the current family dispute among so-called "soft" and "hard" positivists. It claims that this dispute shows that contemporary legal positivism has rejected the important original insight that originally identified it. Legal positivism was born as a theory of modern law, a form of law that was artificially and contingently made rather than discovered thorugh the use of reason. the current state of legal theory and practice shows the need to return to this "ethical" version of legal positivism, because we are witnessing a sort of legal involution to pre-modern legal forms that is sometimes called "neo-constitutionalism", involution that -if legal positivism's original insight is still valid, as this article claims it is- ought to be resisted. Such a strong "ethical" theory must understand legislation as the non plus ultra of law, and judges as "underworkmen" of the legislator, without reducing adjudication to a mechanical activity that loses sight of the particulars involved. 
[Brian y una célula del People's Front of Judea han ingresado al palacio de Poncio Pilatos con el plan de secuestrar a la mujer de Pilatos y formular exigencias a cambio de su liberación. Ahí se encuentran con otro grupo anti-romano, la Campaign for Free Galilee. Ambos grupos comienzan a luchar entre sí. Brian interviene]

BRIAN: Brothers! Brothers! We should be struggling together!

FRANCIS: We are! Ohh.

BRIAN: We mustn't fight each other! Surely we should be united against the common enemy!

EVERYONE: The Judean People's Front?!

BRIAN: No, no! The Romans!

EVERYONE: Oh, yeah. Yeah. Yeah. Yes.

Monty Python's Life of Brian (1979)

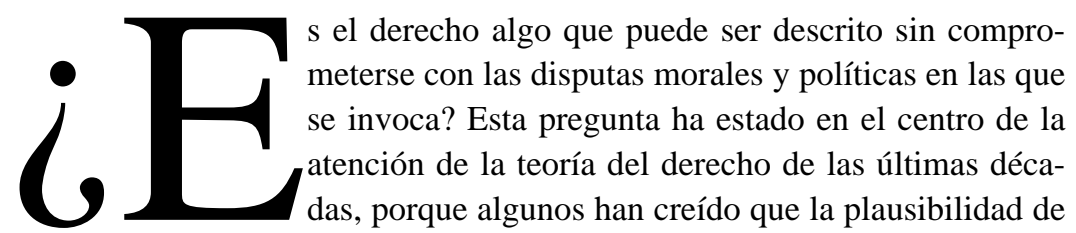

lo que suele llamarse “positivismo jurídico” depende de su respuesta. Aquí se ofrecen razones para responder negativamente esta pregunta; para dudar, en consecuencia, de la importancia de la actual controversia entre diferentes versiones de esa escuela. Pero eso no quiere decir que la idea central del positivismo jurídico deba ser desechada, cuando ella es correctamente identificada. Eso es lo que intentaré hacer a continuación: rescatar una compresión del positivismo jurídico de acuerdo a la cual éste no pretende que el derecho pueda ser estudiado “descriptivamente”, que la teoría del derecho deja las cosas, parafraseando a Wittgenstein, tal como estaban. En su mejor versión, el positivismo jurídico es una teoría del derecho moderno que por tanto no puede ser entendido sin remitirse a los valores que el derecho moderno pretende (contribuir a) realizar. Al rechazar la factibilidad de una teoría del derecho puramente conceptual abrimos el camino a una teoría del derecho cuya preocupación central es su contribución a la mantención del valor que es posible encontrar detrás de nuestras prácticas jurídicas, si es que es posible encontrar alguno. El positivismo ético como teoría del derecho se concentra, por eso, en la formalidad y la autonomía del razonamiento jurídico. Pero la razón por la cual la formalidad y la autonomía del derecho son importantes no es que sólo ellas asegura niveles aceptables de certeza y seguridad, que es la usualmente invocada en estos contextos. En la versión que intentaré defender, el positivismo jurídico defiende una comprensión del derecho de acuerdo a la cual éste puede ser un instrumento de autogobierno democrático. El autogobierno democrático sólo es posible si es posible una forma de discurso jurídico formal y (relativamente) autónomo, cuya autocomprensión corresponde al positivismo ético. Para ser estable, esa forma 
de positivismo debe evitar el formalismo exagerado del positivismo jurídico europeo del siglo XIX y reconocer que nuestras prácticas jurídicas son tales, que los jueces simplemente no pueden ser meras bocas que pronuncian las palabras de la ley. Pretender defender esta concepción de la adjudicación lleva a la inestabilidad de la práctica jurídica, como fue identificado por Bentham. La necesidad de una teoría del derecho que celebre la contingencia y autonomía del derecho moderno es particularmente aguda en la actualidad cuando empieza a consolidarse un paradigma alternativo llamado a veces “neo-constitucionalismo”. El neo-constitucionalismo constituye, por razones que serán expuestas en su momento, una involución a formas legales pre-modernas que en las circunstancias actuales implica la disolución del derecho. Para resistirlo se necesita una teoría que, como el positivismo del siglo XIX, entienda a la ley como el non plus ultra del derecho pero que, a diferencia de él, evite reducir la adjudicación a una actividad mecánica que pierda de vista los casos particulares involucrados. El positivismo jurídico fue en sus orígenes una teoría de este tipo, y es esa forma de la teoría la que debe ser rescatada de quienes hoy reclaman la etiqueta. Éste es el plan de este artículo.

\section{Una disputa de familia}

Desde un tiempo a esta parte en la teoría del derecho ha surgido una curiosa disputa de familia entre los así llamados 'positivistas'. Es hoy un lugar común identificar el origen de esta disputa con el ataque que la familia sufrió en la forma de la crítica de Ronald Dworkin a El Concepto de Derecho de H.L.A. Hart. Los argumentos de Dworkin se concentraron originalmente en lo que él llamó 'principios', cuya validez se fundaba en su corrección material y no en el hecho de ser formalmente reconocidos conforme a una regla de reconocimiento. Enfrentado a los principios, Hart parecía forzado a elegir una de dos posiciones igualmente insatisfactorias: o declaraba que los principios eran inválidos en tanto no fueran reconocidos por la regla de reconocimiento, o aceptaba que algunas normas jurídicas podían ser válidas en virtud de sus méritos substantivos (por ser justas, correctas, imparciales, etc), aun cuando no pudieran ser reconocidas formalmente.

Hart, por desgracia, no vivió lo suficiente para entregar su propia respuesta final y reflexionada al desafío (lo que después fue publicado como el postscriptum a su libro principal quedó inconcluso ${ }^{1}$ ), de modo que el desafío pasó a sus herederos. Aquí empezó la batalla de familia. Algunos

\footnotetext{
${ }^{1} \mathrm{Y}$ hay razones para pensar que de haber tenido la posibilidad de revisarlo antes de la publicación habría hecho cambios sustantivos. Véase Dworkin, "Hart’s Postscript”, 1. Véase adicionalmente Lacey, A Life of H.L.A. Hart, 328-353.
} 
positivistas adoptaron una línea de respuesta conciliadora, 'suave' o 'blanda', aceptando que los principios podían ser parte del derecho a pesar de ser reconocidos por su contenido, y asumiendo a una definición más débil del clan (según la cual el positivismo jurídico es una familia de teorías jurídicas unidas por la tesis de que no hay una conexión necesaria, a pesar que puede haber una conexión contingente, entre el derecho y la moral). Otros adoptaron la estrategia "estricta” o "dura” de negar a los principios estatus jurídico tout court y parapetarse en la versión más fuerte de la teoría, según la cual el derecho no sólo es basado en fuentes, sino válido porque es basado en las fuentes (por tanto los principios, válidos porque son substantivamente correctos y no necesariamente porque son basados en alguna fuente, no son derecho válido²).

Lo que siguió es el patrón usual de las disputas de familia: los suaves sostuvieron que la familia no sobreviviría a menos que adoptara una visión más "inclusiva” de sí misma, mientras que los duros retrucaron que los suaves se estaban rindiendo al oponente. La disputa continuó y continúa.

Observo esta controversia no como un perfecto extraño. Más abajo, espero, quedará claro por qué me veo como un pariente lejano, que vuelve a casa después de cierto tiempo y ve con desazón que ambos bandos, como usualmente ocurre en las disputas de familia, pierden de vista algo realmente importante, que por defender a la familia según cada uno la entiende, están inconscientemente traicionando la idea misma que la animaba. Más aún, creo que hoy esta idea está bajo un serio ataque representado por el así llamado "neo-constitucionalismo", y que es éste el desafío que debe importar a los "auténticos" positivistas jurídicos. La paradoja está en que los positivistas contemporáneos no sólo han dejado de preocuparse de esto, como si simplemente hubiesen comenzado a discutir otra cosa; por el contrario, están positivamente contribuyendo a la erosión del espíritu original del positivismo.

\section{Los duros}

Los duros responden a Dworkin lo que Margaret Thatcher (dice que) respondió a Europa mientras era primer ministro: "No, No, No". Sostienen que el positivismo jurídico se identifica con la tesis que todo el derecho es basado en fuentes sociales, lo que quiere decir que sólo las normas que pueden identificarse y cuyo contenido puede ser determinado descansando sólo en hechos sociales pueden ser llamadas propiamente normas "jurídicas”. Esto implica que una norma cuyo contenido o identificación depende

\footnotetext{
${ }^{2}$ Más sobre el significado e importancia de este “porque” abajo.
} 
de la satisfacción de ciertos criterios morales (como las que son válidas por satisfacer esos criterios o las que se refieren a conceptos morales, de manera que para establecer su significado se requiere establecer cuál es la "correcta" comprensión de esos conceptos) no es parte del derecho. Según la tesis de las fuentes, "la existencia y el contenido del derecho es materia de hechos sociales que puede ser establecida sin referirse a argumentos morales"

No entraré a analizar en detalle las premisas utilizadas por los así llamados positivistas "excluyentes" para justificar una posición tan dura, en parte porque son conocidas, en parte porque me he referido a ellas en el pasado $^{4}$, pero principalmente porque una vez que veamos -como lo haremos pronto- que las conclusiones del argumento son inaceptables, la tarea de encontrar los aspectos de esas premisas que deben abandonarse, corregirse $o$ modificarse no necesita entretenernos, porque desde ese momento la disputa se revelará como lo que efectivamente es: una disputa sobre la propiedad o impropiedad de utilizar la palabra "derecho" para etiquetar ciertas normas o sistemas normativos.

En vez de examinar los fundamentos de la posición de los duros quiero considerar sus implicaciones. En particular, quisiera detenerme a examinar lo que diría uno de ellos sobre los sistemas jurídicos que conocemos, los que nos preocupan cuando nos desplazamos de cuestiones conceptuales hacia nuestras preocupaciones normales como abogados, profesores de derecho positivo o científicos del derecho.

Una consecuencia aparente de la tesis de las fuentes en su sentido más duro es que la mayor parte de lo que describiríamos usando la palabra "derecho" resulta, examinado con detención, no ser derecho. En muchos países (especialmente en países que tienen constituciones rígidas y un sistema de control difuso de constitucionalidad de la legislación, aunque el argumento es aplicable a otros casos menos peculiares), el derecho legislado no sería derecho, puesto que su validez está sujeta a la condición de que el contenido de las leyes no viole ciertas normas constitucionales de redacción amplia y moralmente cargada. Las condiciones de verdad de la afirmación "La ley $\mathrm{X}$ es derecho chileno (argentino, norteamericano, etc) válido" incluyen que $\mathrm{X}$ no sea incompatible con los derechos fundamentales incorporados en las disposiciones relevantes de la constitución chilena (argentina, norteamericana, etc). Así por ejemplo, la validez de cualquier ley norteamericana que

\footnotetext{
${ }^{3}$ Raz, “Authority, Law and Morality”, 218 [253]. En general, cuando se citan obras en inglés de las cuales conozco traducción en español se indica en primer lugar la paginación en el original y entre corchetes la paginación en la traducción. Los datos de ambas se incluyen separadamente en la bibliografía. Las citas en castellano de esas obras son por regla general mis traducciones.

${ }^{4}$ Atria, Law and Legal Reasoning.
} 
establezca una pena para cualquier acción depende de que sea compatible con la octava enmienda, que prohíbe los castigos crueles e inusuales. Por supuesto, es claro que en el sentido relevante una multa moderada para un falta moderada no es cruel, pero la tesis de las fuentes no es una tesis sobre la controversialidad de las fuentes del derecho, y lo que excluye no son consideraciones morales controvertidas sino consideraciones morales porque son consideraciones morales ${ }^{5}$. Como la cuestión de si una multa moderada es "cruel" en el sentido de la octava enmienda es una cuestión moral -una muy simple, con una respuesta obvia si se quiere, pero a pesar de todo moral- y si la validez de una ley depende de ella, esa ley no sería entonces derecho, porque para poder afirmar su existencia es necesario argumentar moralmente sobre la no crueldad de ese castigo. El mismo argumento vale para toda ley chilena que pueda implicar discriminación (art. 19 No 2 constitución chilena), para toda ley argentina que parezca imponer sanciones a conductas "privadas de los hombres, que de ningún modo ofendan al orden y a la moral pública ni perjudiquen a un tercero" (art. 19 segunda parte constitución argentina), etc.

En consecuencia el positivista duro parece forzado a concluir que ninguna de esas leyes chilenas, argentinas o norteamericanas es derecho. Lo mismo puede predicarse de todos los contratos (en Chile al menos, la validez de un contrato está sujeta a la condición de que no sea contrario a la "moral" y "las buenas costumbres", de acuerdo al art. 1461 del Código Civil, y esta disposición no es particularmente idiosincrásica), los decretos, reglamentos, etc $^{6}$. El positivismo excluyente parece restringir de tal forma la extensión de la palabra "derecho", que la categoría de las normas legales es casi vacía.

(Es sólo "casi vacía” y no vacía, porque estrictamente hablando sólo incluye las normas particulares cuya validez puede fundarse en el hecho

\footnotetext{
${ }^{5}$ La tesis de las fuentes "no implica la falsa proposición que todas las materias fácticas son pacíficas, ni tampoco la falsa visión que todas las proposiciones morales son controvertidas" (Raz, “Authority, Law and Morality”, 218 [253]); ver también Marmor, Positive Law, 51-52.

${ }^{6}$ Sin notar que los mismos argumentos se aplican no sólo a los contratos sino también a las leyes, esto es lo que T Endicott llama "la parte sorprendente" de la teoría del derecho de Raz (Endicott, "Raz on gaps", 99). Endicott encuentra sorprendente un argumento que parece implicar que "no hay derecho inglés de contratos" (ibíd., 102). Él argumenta que "una exigencia jurídica de aplicar consideraciones morales confiere discreción a los tribunales, pero sólo porque las consideraciones morales son vagas” (ibíd., 100). La posición de Endicott, entonces, es incompatible con la tesis de las fuentes, a pesar de que no quiera decirlo. Después de todo los argumentos de Endicott hacen de la controversialidad el criterio para la discreción. Creo que esto no puede ser correcto: no podemos decir que un caso es difícil si y sólo si hay desacuerdo entre los participantes acerca de la solución correcta, puesto que puede haber desacuerdo por muchas razones (basta considerar la posibilidad del comportamiento estratégico, que después de todo es para lo que se les paga a los abogados). Pero este no es el lugar para discutir este asunto. Véase Atria, Law and Legal Reasoning, 73-74.
} 
social de haber sido dictadas por un juez y que hayan adquirido autoridad de cosa juzgada. Es irónico que en su defensa del positivismo los duros terminen con un concepto de derecho como "órdenes (del juez) respaldadas por amenazas"7).

Pero esta parece una conclusión absurda, por lo que cualquier positivista, por duro que sea, intentará evitarla para mantener la plausibilidad conceptual. Por eso debemos considerar algunos de sus mejores esfuerzos para evitarla.

Validez prima facie. Uno podría sostener que las leyes y los contratos no son legalmente válidos de manera concluyente hasta que un tribunal no haya dicho que lo son. Como una decisión jurisdiccional es un hecho social, después del fallo existe un hecho social para sostener la validez de la norma (contractual o legal) contenida en la sentencia. Así Raz creía que podía evitar que su compromiso con la tesis de las fuentes lo llevara a concluir que los contratos no son derecho cuando hay una regla (como el ya mencionado art. 1461 CC) que dispone que los contratos no son válidos si no cumplen algún criterio moral. En este caso,

Para determinar la validez de un contrato en particular uno debe referirse a un argumento moral. Sólo después de que la validez del contrato ha sido declarada por un tribunal ella puede ser establecida de acuerdo a la tesis de las fuentes, i.e. por referencia a la decisión jurisdiccional. Por eso la tesis de las fuentes implica que antes de la decisión jurisdiccional de ningún contrato puede decirse que es válido de manera conclusiva. Por supuesto, estos contratos son válidos prima facie, si cumplen con otros criterios de validez exigidos por la ley ${ }^{8}$.

Pero decir que el contrato es válido prima facie es decir que el tribunal no tiene ninguna obligación jurídica de reconocerlo como jurídicamente válido: "en virtud de la tesis de las fuentes los tribunales tienen discreción cuando se les requiere para que apliquen consideraciones morales”. En consecuencia, el tribunal no puede estar legalmente equivocado al decidir si un contrato es válido o inválido (y recuérdese que esto se dice no para casos especialmente objetables de contratos, como el contrato entre Antonio y Shylock en El Mercader de Venecia, sino para todo contrato, para cada contrato).

En lo que se refiere a la ley, esta idea de validez prima facie enfrenta otra objeción, más seria. Una decisión jurisdiccional relativa a la validez de un

\footnotetext{
${ }^{7}$ Como correctamente sostienen Moreso y Vilajosana, Introducción a la Teoría del Derecho, 198, el escepticismo realista es una consecuencia (una “exageración”, advierten ellos) de la tesis de las fuentes. Veremos que con menos exageración de la que ellos parecen requerir el positivismo analítico llega a consecuencias escépticas.

${ }^{8}$ Raz, El Concepto de Sistema Jurídico, 257-8. Véase también Raz, “Legal Reasons”, 75.

${ }^{9}$ Raz, “Legal Reasons”, 75.
} 
contrato usualmente produce cosa juzgada, en el sentido que el asunto queda decidido de manera concluyente. Pero en muchos sistemas jurídicos las decisiones judiciales en casos de constitucionalidad de una ley no producen res iudicata. Ahora bien, en algunos países (e.g. Estados Unidos y Argentina) existe lo que es a veces denominado un sistema de control difuso de constitucionalidad, que puede (o no) existir junto a una regla de stare decisis. Una decisión en el caso $\mathrm{X}$ en el sentido que una ley es contraria a la constitución implica que la ley es inaplicable al caso concreto en que la sentencia es dictada. Pero por sí misma esa decisión no implica nada para otros casos. Esta labor es realizada por la regla del stare decisis, según la cual los tribunales inferiores están obligados por las decisiones de los tribunales superiores ${ }^{10}$. Esto es, si la Corte Suprema argentina decide que una ley es constitucional, y en consecuencia aplicable a un caso particular, esta decisión produce cosa juzgada en el caso (en el contexto de ese caso el hecho de la constitucionalidad de la ley no puede plantearse nuevamente), pero no obliga al mismo tribunal a fallar de igual manera el siguiente caso ${ }^{11}$. Lo mismo puede ocurrir en países con sistemas concentrados de adjudicación constitucional (en los que un tribunal constitucional al estilo europeo tiene el poder de derogar leyes en sede de inconstitucionalidad), en los que el tribunal constitucional no necesariamente está obligado por decisiones previas.

Si aplicamos la idea de Raz de validez prima facie a las leyes en sistemas como los mencionados, veremos que la validez así limitada se mantiene incluso después de que un tribunal ha rechazado una demanda de inconstitucionalidad; en efecto, el mismo tribunal retiene el poder para cambiar de opinión y decidir de otra manera en un caso futuro; a diferencia de un contrato, la constitucionalidad de una ley puede discutirse con referencia a un caso distinto en el futuro. En consecuencia, nunca será el caso que la validez de una ley satisfaga de manera concluyente la tesis de las fuentes. En lo que concierne a la ley, los jueces siempre tendrán discreción.

Potestades jurídicas limitadas y dirigidas. Tal vez por estas razones algunos positivistas duros han rechazado la idea de validez prima facie. Andrei Marmor ha sostenido, incluso, que la idea de validez prima facie es

inconsistente con la naturaleza autoritativa del derecho, [porque] la autoridad existe para hacer una diferencia práctica, y no podría pretender hacer tal diferencia si las directrices autoritativas sólo fueran válidas prima facie [...] Es como si la autoridad dijera: 'hagan lo que les digo, a menos que lo que les digo sea

\footnotetext{
${ }^{10}$ Véase Guastini, “La constitucionalización del ordenamiento jurídico: el caso italiano”, 53s.

${ }^{11}$ Este no es sólo un punto académico. Durante los años ' 80 y '90 la interpretación de la constitución argentina por la Corte Suprema de ese país osciló notoriamente. Véase, por ejemplo, Böhmer, "La corte de los '80”.
} 
contrario a razones morales'. La validez jurídica no es una construcción prima facie. La autoridad del derecho se necesita precisamente para hacer concluyentes, al menos desde un punto de vista jurídico, razones prima facie que se aplican a los sujetos putativos ${ }^{12}$.

En vez de sostener que las normas jurídicas que estamos considerando son válidas prima facie, Marmor entiende que ellas "funcionan como reglas que otorgan a los jueces poderes legislativos limitados y guiados"13. Así, para usar el ejemplo discutido por Marmor, la octava enmienda de la constitución norteamericana otorga a los tribunales autoridad legislativa ("limitada y guiada”) para invalidar normas jurídicas que contengan penas crueles. La potestad que conceden es limitada y guiada porque la norma jurídica que otorga tal potestad (i.e. la octava enmienda) especifica la clase de razones en las cuales el tribunal puede apoyarse para invalidar una determinada ley y también prohíbe a los tribunales invalidar leyes por otras razones (los tribunales no pueden declarar, ejemplifica Marmor, una forma de castigo inconstitucional porque de acuerdo a su opinión es económicamente ineficiente ${ }^{14}$ ).

Marmor toma esta idea de potestades dirigidas de Raz. Raz cree que al conferir estas potestades, "el derecho crea razones para el establecimiento de nuevas reglas jurídicas, aunque éstas no son parte del derecho hasta que sean establecidas por la autoridad competente”15. De este modo puede responderse satisfactoriamente la pregunta: “¿cómo puede el derecho permitir la creación de una nueva regla sin que esa regla ya sea parte del derecho en virtud del hecho de que puede ser creada?”16. Las potestades dirigidas otorgan competencia a algunas autoridades para crear derecho, luego si el derecho contiene una regla que confiere potestades dirigidas, podemos decir: (1) que la potestad que ese órgano detenta en virtud de tal regla es una potestad jurídica, porque es conferida por una regla jurídica, y (2) que es dirigida, porque el contenido de la potestad conferida a la autoridad competente está limitado por la regla que confiere la potestad.

Marmor, entonces, no entiende la octava enmienda como una regla que prohíbe castigos crueles e inusuales, sino como una que autoriza a los tribunales a invalidar una ley cuando imponga castigos que a su juicio lo sean; para esos efectos, supondremos, con Marmor, que "la cuestión de qué clase

\footnotetext{
${ }^{12}$ Marmor, Positive Law, 64.

13 ibíd., 67.

${ }^{14}$ ibíd.

${ }^{15}$ Raz, "Inner logic of the Law”, 226 [263s].

${ }^{16}$ ibíd., 228.
} 
de castigos son crueles es una cuestión moral"17. Hasta ahora hemos preguntado cuáles son las consecuencias de la octava enmienda para el estatus jurídico de las normas jurídicas norteamericanas que imponen penas, porque esa enmienda parece sujetar la validez de esas normas a una condición que no satisface la tesis de las fuentes: que las penas que impongan no sean crueles. Pero ahora debemos preguntarnos por el estatus de esta norma, la octava enmienda misma, y la conclusión debe ser que no puede ser parte del derecho porque también falla la prueba de la tesis de las fuentes. La falla porque su contenido no puede ser determinado sin referencia a consideraciones morales. Si determinar qué castigos son crueles es una cuestión moral, la pregunta por el contenido de la octava enmienda no puede ser contestada sin responder la pregunta por el concepto moral de crueldad. Pero por supuesto, si la octava enmienda no es una norma jurídica (=no satisface la tesis de las fuentes), entonces las potestades que ella confiere no pueden ser potestades jurídicas, y las limitaciones que ella impone a esas potestades no pueden ser limitaciones jurídicas (supongo aquí que para decir que una potestad es una potestad jurídica es necesario que una norma jurídica la otorgue, constituya, reconozca, etc).

El punto central aquí es que de acuerdo al positivismo duro una norma jurídica no puede conferir una potestad jurídicamente dirigida o limitada si los estándares que dirigen y limitan la potestad no satisfacen la tesis de las fuentes. En consecuencia, cuando los jueces ejercen estas potestades, no están jurídicamente dirigidos y la razón para ello es doble: porque la norma que confiere potestad no calificaría como una norma "jurídica", puesto que su contenido no puede ser determinado sin tomar en cuenta consideraciones morales (sin resolver el problema moral de qué penas son crueles no podemos determinar el contenido de la octava enmienda), y además porque aun si la norma que confiere potestades es jurídica, los estándares que de acuerdo a ella dirigen las potestades así conferidas (i.e. los estándares que determinan qué penas son o no crueles) son de todas formas estándares morales. La primera razón nos dice que estas potestades no pueden ser potestades jurídicas, la segunda que aun si lo fueran no pueden ser jurídicamente dirigidas o limitadas. La idea de potestades dirigidas y limitadas tampoco sirve para evitar nuestra conclusión absurda.

Definitividad e Infalibilidad. Que el positivismo duro lleva al escepticismo ante las reglas no debe sorprendernos, porque cuando se enfrenta a normas como la octava enmienda se ve forzado a eliminar la distinción in-

\footnotetext{
${ }^{17}$ Marmor, Positive Law, 67. Aunque esta estipulación pasa de lado por un problema importante, al cual tendremos que volver cuando veamos lo que sostienen los positivistas suaves.
} 
troducida por Hart para responder a la objeción escéptica: la distinción entre definitividad e infalibilidad ${ }^{18}$. Marmor es bastante claro en esto:

Supongamos que desde un punto de vista moral la pena de muerte es realmente cruel y en consecuencia no debería ser válida. A pesar de ello, desafortunadamente la Corte Suprema ha decidido de otra manera. ¿Deberíamos continuar afirmando que las leyes que prescriben la pena de muerte hoy en Estados Unidos no son legalmente válidas? Y si es así, ¿cuál es la significación práctica de la autoridad de la Corte Suprema que ha decidido de otra manera? ${ }^{19}$.

Marmor parece estar ofreciendo, como un argumento a favor de la tesis de las fuentes, el hecho que todos los sistemas jurídicos especifican las oportunidades en que las decisiones judiciales pueden ser cuestionadas. Esto equivale a hacer posible una res iudicata que implica que la decisión es válida sin importar si en derecho ella es correcta o no ${ }^{20}$. Marmor sostiene que esto afirma la comprensión de los duros de la tesis de las fuentes, pero no parece darse cuenta que, en realidad, el argumento así entendido prueba mucho más. Es evidente que un tribunal puede, equivocadamente, decidir que la pena de muerte no es cruel, así como puede decidir que la internación de ciudadanos norteamericanos de origen japonés en los Estados Unidos durante la II Guerra Mundial o la doctrina de “separados pero iguales” no implican desigual tratamiento de las leyes. Como estas decisiones no pueden ser impugnadas jurídicamente, Marmor concluye que ellas no pueden ser legalmente erradas (porque no hay nada acerca del derecho respecto de lo cual se puedan equivocar), y que ésta es la razón por la que son válidas, que son inatacables porque no son incorrectas. En realidad es más sensato decir que esas decisiones no pueden ser impugnadas a pesar de ser equivocadas, y no porque no puedan ser equivocadas. De hecho, el mismo Marmor ha concedido esto en el argumento anterior: ¿no era el caso que las normas que hacen referencias a conceptos morales confieren potestades limitadas y dirigidas? ¿qué pasa si una corte viola esas limitaciones o no respeta esas directrices? ¿qué ocurriría si la Corte Suprema decidiera (invocando un argumento utilitarista tan obvio que es innecesario mencionarlo) que la pena de muerte debería ser declarada cruel porque es altamente ineficiente desde un punto de vista económico?

Pero el problema es más grave, porque el argumento de Marmor es aplicable en general no sólo a los estándares no basados en fuentes que dirigen y limitan las potestades legales sino a todas las normas. Por ejemplo:

\footnotetext{
${ }^{18}$ Véase Hart, Concept of Law, 141-147 [176-183].

${ }^{19}$ Marmor, Positive Law, 64.

${ }^{20}$ A hacer posible, en otros términos, una decisión vinculante (Raz, Practical Reason and Norms, 135s [155ss]).
} 
Donde una ley otorga el doble de las costas [...] se calculan como sigue: las costas comunes, y luego la mitad de las costas comunes; si hay costas triples: $1^{\circ}$ las costas comunes, $2^{\circ}$ la mitad de éstas, $3^{\circ}$ y luego la mitad de estas últimas ${ }^{21}$.

Si ésta es la decisión final del tribunal, entonces el triple de 100 es 175 en lugar de 300 porque, como Hart señaló, después de la sentencia definitiva "la afirmación de que el tribunal se "equivocó" carece de consecuencias en el sistema”22. Pero ¿qué se sigue de esto? Lo único que se sigue es que el tribunal ha cometido un error o que ha usurpado las potestades del legislador. Lo que no se sigue es precisamente la conclusión que Marmor necesita: que la decisión de que "triple” significa "multiplicado por 1.75" vale y es incuestionable porque no es jurídicamente incorrecta. Lo atinado aquí es decir, por supuesto, que la decisión vale y es incuestionable a pesar de no ser jurídicamente correcta. La posibilidad de que la Corte Suprema se equivoque al identificar los castigos verdaderamente crueles (y de que lo que la Corte erradamente decida pueda adquirir autoridad de cosa juzgada), por consiguiente, podrá mostrar muchas cosas, pero no muestra que la obligación de los tribunales de derogar las leyes que establecen la pena de muerte es menos jurídica que la obligación de los tribunales de decidir que "triple” es “multiplicado por tres" (y no por 1.75). Si Marmor quisiera llegar a esta conclusión, entonces comenzaría a jugar al juego inventado por Hart, discreción del tanteador ${ }^{23}$. Y ciertamente a esto equivale el positivismo jurídico duro: total discreción para el juez, escepticismo radical ${ }^{24}$. Cómo se llega a esta posición escéptica, varía de acuerdo a la línea argumentativa escogida: puede ser porque hoy en día en la mayoría de los países occidentales la validez de las normas jurídicas depende de que cumplan con ciertos requisitos morales incorporados en la constitución (por lo que las leyes no son normas jurídicas, porque su existencia no puede ser fundada sólo en hechos sociales), o porque todas las leyes en estas circunstancias gozan solamente de una forma de validez prima facie, de manera que no obligan al juez (ni, ciertamente, a cualquiera) de manera concluyente, o porque la

\footnotetext{
${ }^{21}$ Un tal "Mr. Palmer”, citado por Bentham, Rationale of Judicial Evidence, 311.

${ }^{22}$ Hart, Concept of Law, 141 [176].

${ }^{23}$ Véase ibíd., 144 [177].

${ }^{24}$ En sus momentos menos cuidadosos los duros parecen darse cuenta de su escepticismo
} radical. Así Raz: “Tal razonamiento [el que lleva a la conclusión de que el contenido del derecho es tal-y-cual] no puede por sí mismo fundar ninguna decisión judicial en los países del common law" (Raz, "Postema on law’s autonomy”). Al respecto, véase Atria, Law and Legal Reasoning, 188-195 (Atria, "Del derecho y del razonamiento jurídico”, 107-117). En otras palabras: del hecho de que de acuerdo al contenido del derecho el juez tenga el deber jurídico de fallar en contra del demandante no se sigue que jurídicamente el juez deba fallar en contra el demandante. 
tesis de las fuentes implica el abandono de la distinción entre definitividad e infalibilidad, transformando nuestras prácticas legales en "discreción del tanteador”. La conclusión es siempre la misma: en los sistemas jurídicos contemporáneos, los jueces no están jurídicamente vinculados al derecho legislado.

\section{Los suaves}

Aquí entran los positivistas suaves. Ellos parecen poder ofrecer una salida, porque sostienen que no hay razón alguna por la que un sistema jurídico determinado no pueda incorporar convencionalmente estándares morales a su regla de reconocimiento. Todo lo que los positivistas suaves necesitan sostener es que tal inclusión es contingente, i.e. depende de que la regla de reconocimiento, convencional como ella es, haga referencia a estándares morales como condiciones o requisitos de identificación del derecho.

Los duros replican que es incompatible con la "naturaleza" del derecho permitir la incorporación de estándares morales a la regla de reconocimiento, aun contingentemente, por dos razones: porque privaría al derecho de la capacidad para tener autoridad, y porque reduciría el derecho a la irrelevancia práctica (parece que ellos creen que el art. 1461 del Código Civil no es capaz de hacer ninguna diferencia práctica para el derecho de contratos). Sin embargo, como no estamos buscando razones para apoyar a una rama de la familia contra la otra, podemos ignorar este aspecto de la disputa.

El positivismo suave no necesita negar que los sistemas jurídicos contemporáneos se remiten a la moral; tampoco debe negar que las normas jurídicas cuya validez depende de que ellas satisfagan algún criterio moral sean realmente normas jurídicas. El positivismo suave corresponde a una versión también suave de la tesis de las fuentes, que insiste solamente en (1) que la moral puede ser incorporada al derecho si existe una convención para tal efecto, y (2) que si la moral es jurídicamente relevante, es porque hay reglas convencionales que la incorporan: es porque, por ejemplo, el derecho norteamericano incorpora una referencia a la cuestión moral de la crueldad en la pena que la moralidad de la crueldad en la pena es jurídicamente relevante; la convención puede modificarse, y también podría hacerlo la relevancia de la cuestión moral.

Antes de continuar con el argumento es necesario, por razones que luego serán evidentes, detenerse en el significado y alcance del "porque" destacado con cursiva en el párrafo anterior. Para aclarar su significado, es útil considerar la principal objeción presentada por H.L.A. Hart a la tesis de Hans Kelsen de la relación entre el derecho nacional e internacional.

Como es sabido, Kelsen creía que el derecho nacional y el internacional eran un solo sistema jurídico. Hart cita la siguiente afirmación de Kelsen: 
“no es lógicamente posible asumir que normas simultáneamente válidas pertenecen a sistemas mutuamente independientes"25. Para Hart, ésta era "una de las doctrinas más sorprendentes que Kelsen haya expuesto en su Teoría General del Derecho y el Estado"26.

Como Hart lo entendía, el principal argumento de Kelsen a favor de la unidad del derecho local y el internacional era que

el derecho internacional contiene, entre sus normas, una que Kelsen denomina 'el principio de eficacia' que determina o es la razón de la validez del orden jurídico nacional ${ }^{27}$.

Dicho en pocas palabras: primero llegamos a la conclusión (como lo hizo Kelsen) de que un sistema jurídico local existe cuando alcanza algún nivel de eficacia. Luego notamos que una norma de derecho internacional (el "principio de eficacia”) autoriza a un individuo o grupo a crear y aplicar un ordenamiento jurídico basado en una constitución efectiva ${ }^{28}$. Parece entonces que podemos afirmar fundadamente que el primer sistema es válido porque es autorizado por el segundo sistema y concluir que ambos son dos secciones de uno y el mismo sistema, "un todo separable"29.

Hart convincentemente argumentó que el razonamiento de Kelsen era defectuoso porque el hecho que la norma N1 autorice la norma N2 no es suficiente para sostener que N1 valida N2. Conociendo la existencia y contenido de estas dos normas todo lo que podemos concluir es que N1 "pretende validar” N2. Pero una "relación de pretensión de validación” no implica por sí misma una relación de validación. Esto puede ser probado fácilmente mediante un experimento mental:

Supongamos que el Parlamento británico [...] aprueba una ley (la Ley de Validez de las Leyes Soviéticas de 1970) que pretende validar las leyes de la Unión Soviética estableciendo que las leyes actualmente vigentes en territorio soviético [...] serán válidas ${ }^{30}$.

Simplemente con observar la existencia y el contenido de la Ley de Validez de las Leyes Soviética de 1970 no podemos concluir que el derecho soviético es válido en la Unión Soviética porque la ley británica lo valida. Por tanto, no podemos concluir que la ley británica valida el derecho so-

\footnotetext{
${ }^{25}$ Kelsen, General Theory of Law and State, 363, citado por Hart, “Kelsen's doctrine”, 309n2 [105n2].

${ }^{26}$ Hart, "Kelsen’s Doctrine”, 309 [105].

${ }^{27}$ ibíd., 318 [114s].

${ }^{28}$ Kelsen, ibíd., 215, cit. por Hart, ibíd 318 [115].

${ }^{29}$ Kelsen, ibíd., 351, cit. por Hart, ibíd 318 [115; la traducción española dice aquí "un todo inseparable” (sic); Hart cita “one separable whole”].

${ }^{30}$ ibíd., 319 [116].
} 
viético; todo lo que podemos concluir es que esa ley pretende validar al derecho soviético. La conclusión de que N1 valida (en lugar de pretende validar) N2, por tanto, no puede obtenerse sabiendo sólo de la existencia y el contenido de ambas normas. Una relación de pretensión de validación corresponde a una relación de validación cuando la autorización concedida por N1 es considerada por los jueces y otros funcionarios como una razón para reconocer la validez de N2. Esto, desde luego, no es más que una aplicación de las explicaciones de Hart sobre el aspecto interno de las reglas. En el contexto de una práctica jurídica determinada es posible decir que una norma valida a otra cuando el hecho de que la segunda ha sido creada del modo o en las condiciones dispuestas por la primera es considerado, por los integrantes de esa práctica, como (parte de) el fundamento de la validez de la segunda. Como lo dijo Hart, en adición a conocer de la existencia y del contenido de las reglas involucradas

Lo que se necesita para que nos podamos mover desde 'esta ley pretende validar leyes aprobadas por $X$ ' a 'las leyes aprobadas por $X$ de hecho obtienen su validez de esta ley’, es que los tribunales o las agencias encargadas de la identificación del derecho en el territorio en cuestión reconozcan una ley particular que pretende conferir potestades a $X$ y la traten como una razón para reconocer también las reglas que pretende validar ${ }^{31}$.

Por lo tanto la tesis del positivista suave de que en ciertos casos los argumentos morales son jurídicamente pertinentes porque una convención los ha incorporado a la regla de reconocimiento no es sólo una tesis que afirma la existencia de la convención y la relevancia de esas consideraciones. La tesis debe ser que la relevancia jurídica de esas consideraciones morales tiene un fundamento convencional en el sentido de que la convención es, para "los tribunales y las agencias identificadoras de derecho del territorio respectivo" la razón por la cual esas consideraciones morales son relevantes.

Positivismo suave por estipulación. Hay buenas razones para creer que nuestras prácticas jurídicas son tales que la importancia de las consideraciones morales en la aplicación de las reglas jurídicas no es contingente en el sentido que no es algo que pueda ser erradicado con sólo cambiar el contenido de las leyes aplicables. De hecho esto es algo que se ha intentado y ha fracasado ${ }^{32}$. Estas razones, sin embargo, no serán examinadas aquí, porque los positivistas suaves podrían replicar que esto puede ser verdad en lo que concierne a todos los sistemas jurídicos con los que estamos familiarizados,

\footnotetext{
${ }^{31}$ Hart, "Kelsen’s Doctrine”, 337 [135].

${ }^{32}$ Me refiero aquí al impulso detrás del movimiento codificador, que buscaba precisamente hacer de la aplicación de las reglas (codificadas) una labor totalmente mecánica. Desarrollo esta cuestión con cierto detalle en Atria, Law and Legal Reasoning, 115-120.
} 
pero no es necesariamente (i.e. “conceptualmente”) verdad. Como ha sostenido recientemente José Juan Moreso,

la remisión a la moralidad es un rasgo contingente y no necesario de los sistemas jurídicos. Dicha remisión es un rasgo sobresaliente de los sistemas constitucionales contemporáneos y [...] de otros muchos sistemas jurídicos. Pero lo que no hallo [...] es un argumento concluyente para afirmar que es un rasgo definitorio, necesario, de todos los sistemas jurídicos. Si son concebibles, posibles, sistemas jurídicos sin remisión alguna a la moralidad, entonces la tesis de la separación conceptual entre el derecho y la moral es verdadera (en la versión de la negación externa) y, por lo tanto, también es compatible con ella la tesis de las fuentes sociales, en su versión débil ${ }^{33}$.

Moreso hace descansar la plausibilidad del positivismo suave en el hecho de que sea concebible, posible una práctica jurídica sin remisión a la argumentación moral en el momento de aplicación. Si este argumento es correcto, entonces el positivismo suave es plausible, porque podemos encontrar prácticas que son lo suficientemente parecidas con las prácticas que identificamos con la palabra "derecho” en las que no habían referencias relevantes a consideraciones morales. Creo que el derecho romano antiguo es un ejemplo de ello ${ }^{34}$. Para los positivistas suaves esta concesión termina la discusión: el suave, como Moreso, no sostiene que los sistemas jurídicos con los que estamos familiarizados no hacen referencia a la moral. De hecho el positivista suave no necesita siquiera sostener que ha existido en la historia una práctica jurídica inmune a la argumentación moral ${ }^{35}$. Jules Coleman ha sostenido la misma tesis de Moreso:

la tesis de la separación compromete al positivismo con la propuesta de que existe al menos un sistema jurídico en el cual la regla de reconocimiento no especifica la existencia de un principio moral entre las condiciones de verdad de cualquier proposición de derecho. Para que el positivismo sea verdadero, entonces, sólo necesitamos poder imaginar un sistema jurídico en el que la existencia de un principio moral no es condición de legalidad para cualquier norma: esto es, mientras se mantenga la idea de un sistema jurídico en el que la verdad moral no es una condición de validez no lleva implícita una contradicción ${ }^{36}$.

Aquí el argumento contra el positivismo suave no es que esa idea es contradictoria. La pregunta debe ser otra: ¿Por qué esto es importante? ¿Por qué

\footnotetext{
${ }^{33}$ Moreso, “A Brilliant Disguise”.

${ }^{34}$ Véase Atria, Law and Legal Reasoning, 49-60.

${ }^{35}$ Porque le basta la posibilidad conceptual de que existiera, aun si fuera el caso que esa posibilidad conceptual nunca se ha materializado en la práctica. Si adicionalmente esa posibilidad conceptual se ha materializado, el argumento del positivista suave parece hacerse más fuerte.

${ }^{36}$ Coleman, “Negative and Positive Positivism”, 29 (el destacado es agregado).
} 
el hecho de que una "práctica jurídica” tal sea imaginable o haya existido cerca de dos mil años atrás nos enseña algo acerca del derecho? ${ }^{37}$.

La razón por la cual la pregunta anterior es relevante puede quizás ser aclarada con una analogía. Con un argumento parecido al del positivista suave, uno podría decir que la conexión entre el concepto de propiedad y el derecho del dueño de excluir a otros del uso de la cosa de su propiedad es contingente, porque podemos imaginar al menos un caso en que el dueño no tenga ese derecho. En consecuencia, la conexión entre ser dueño de una cosa y tener derecho a excluir a otros de su uso y goce, podríamos decir, es simplemente contingente; el hecho de que en la mayoría de los sistemas jurídicos la posición de dueño de una cosa normalmente implique el derecho del dueño a excluir a otros del uso y goce de la cosa no nos enseña nada sobre el "concepto" de propiedad.

Aquí, como antes, debe ser concedido que en algunos casos los propietarios no tienen derecho a excluir a otros del uso de la cosa. De ahí, sin embargo, no se sigue la conclusión de que la posibilidad de excluir a otros del uso y goce de la cosa es irrelevante desde el punto de vista de la caracterización del concepto de propiedad. En realidad equivale a una estipulación sobre el uso de la palabra. En efecto, la "tesis de la separación” en relación con el dominio no dice nada acerca del dominio, pero sí acerca de “dominio”, i.e. acerca de la palabra “dominio”. Supongo que si uno fuera a desarrollar una teoría del dominio sería sensato entender que el derecho del dueño a excluir a otros del uso de la cosa y la facultad de éste de hacer con la cosa lo que desee estarían en el centro del análisis; después de desarrollar una teoría a partir de elementos centrales como éstos uno tendría que tratar de acomodar los casos especiales en los que ellos no están presentes; se tratará, por ejemplo, de limitaciones internas del derecho de dominio (e.g. sólo parece ser dueño pero es en realidad usufructuario), de casos excepcionales en que por consideraciones externas al dominio éste se ve limitado en su intensidad, de la función social del dominio, etc. Seguramente sería absurdo comenzar al revés, declarando que hay una separación conceptual entre el "concepto" de dominio y todas y cada una de las potestades que el dueño típicamente tiene, y después tratarlas como si fueran simplemente disposiciones contingentes, al mismo nivel conceptual que el lapso exigido por la ley para adquirir por usucapion.

El mismo razonamiento se aplica a la tesis de la separabilidad. A la pregunta de si esas prácticas imaginarias de Coleman, o las prácticas jurídicas concebibles o posibles de Moreso, son instancias que deben ser consideradas como casos tan centrales de "derecho” como los sistemas jurídicos de-

${ }^{37}$ Creo que el mismo argumento está en Waldron, “Normative Positivism”, 220-222. 
sarrollados que conocemos, los positivistas suaves no pueden sino responder con una estipulación de acuerdo a la cual como todas ellas son etiquetadas con la palabra "derecho", todas ellas son igualmente centrales. No importa que la referencia a conceptos morales sea una de las características centrales de todas las prácticas jurídicas que conocemos, es simplemente contingente y desprovista de cualquier interés "conceptual”. Así es como debemos usar la palabra "derecho". La tesis suave de la separabilidad es en consecuencia una definición puramente estipulativa, y como tal tan inobjetable como poco interesante.

Deformación como precio de la coherencia. Algunos positivistas suaves aceptan un argumento como el anterior, sosteniendo que "si el positivismo ha de ser una tesis interesante, debe aceptar, pero ir más allá de, la tesis de la separación"38. La manera de ir más allá es insistir en la naturaleza convencional del criterio de validez. Aquí nos desplazamos a la segunda implicación de la postura del positivismo suave: si la moral es jurídicamente relevante es porque existe una convención para esos efectos.

Recuérdese, nuestro ejemplo estándar ha sido la octava enmienda a la constitución de Estados Unidos, que prohíbe al legislador imponer "penas crueles e inusuales". Como hemos visto, la cláusula "cruel e inusual” incorpora la moral al derecho norteamericano, pero lo hace en una forma convencional, dice el positivista suave: sólo porque los norteamericanos están de acuerdo en sujetar la validez de las reglas punitivas a un estándar de justicia y decencia especial es que ese estándar de justicia y decencia especial es parte del derecho.

Las cosas, sin embargo, no son tan simples: en realidad es difícil decir que en la practica norteamericana haya una convención según la cual la referencia a "castigos crueles o inusuales" deba ser entendida como una referencia al concepto moral de crueldad. Hay quienes creen que la octava enmienda hace referencia a hechos tales como las creencias o intenciones de los founding fathers u otras cosas por el estilo. Ésta es una materia controvertida en el derecho constitucional norteamericano. Los así llamados "interpretativistas", creen que el concepto moral de crueldad es constitucionalmente relevante a pesar de saber mejor que los teóricos del derecho que hay desacuerdo al respecto al interior de la práctica jurídica norteamericana, y los llamados "no-interpretativistas" creen que no hay nada moral involucrado en la determinación de si el contenido de una pena es cruel, lo que debe ser respondido sobre la base de las intenciones originales de los

${ }^{38}$ Coleman, “Authority and Reason”, 316. 
constituyentes $^{39}$. Por lo tanto, en esta materia, si hay una cosa en que ambos parecen estar de acuerdo es en la falsedad de la tesis del positivista suave: ambos creen que la moral de la crueldad (aplicada a las penas) no es parte del derecho constitucional norteamericano en virtud de razones convencionales.

Si no existe tal convención, los positivistas suaves podrían retroceder y sostener que la tesis de la separación implica que la posición por defecto es que la moral no está incorporada (se necesita una convención para incorporar la moral, no se necesita una convención para no incorporarla). En consecuencia, el hecho de que exista desacuerdo haría del positivista suave un originalista. Pero es claro que los positivistas suaves querrían que su teoría acerca del “concepto” del derecho fuera agnóstica en materias como estas, y tendrían una buena razón para ello: los abogados norteamericanos (chilenos, argentinos) probablemente tienen mayor conocimiento del derecho norteamericano (chileno, argentino) que los teóricos del derecho.

¿Qué podría responder el positivista suave en este punto? Podría reclamar que estamos tratando de un caso de los que Hart denominó de incerteza sobre la regla de reconocimiento. La regla de reconocimiento es una práctica, y no hay razón para que esa práctica deba caracterizarse por límites precisos y contenidos claros e incontrovertibles para todos ${ }^{40}$. Pero el precio pagado para obtener coherencia de este modo es muy alto. Recordemos que el asunto es determinar cómo debemos entender (supongamos) disposiciones constitucionales que establecen lo que parecen ser limitaciones substanciales a la potestad legislativa, tal como la octava enmienda a la constitución de Estados Unidos, o una lista de derechos fundamentales y sus semejantes común en prácticamente todas las constituciones escritas. No podemos afirmar que esta es una cuestión marginal ${ }^{41}$. Pero una teoría convencionalista del derecho puede aceptar la incerteza en la regla de reconocimiento sólo cuando es marginal:

Aquí, en la periferia de estas cosas verdaderamente esenciales, deberíamos dar la bienvenida al escéptico ante las reglas, mientras él no olvide que es en la periferia donde es bienvenido ${ }^{42}$.

${ }^{39} \mathrm{Al}$ usar estas etiquetas no las hago mías (las usa, por ejemplo, Ely, Democracy and Distrust, 1). En realidad, creo que ellas son tendenciosas (véase Dworkin, "Forum of Principle”, 34-38), pero por razones que no tienen que ver con el argumento desarrollado aquí.

${ }^{40}$ Véase Hart, Concept of Law, 147-154 [183-191].

${ }^{41}$ De hecho, ni siquiera es claro lo que "marginal” puede significar en este contexto: véase Waldron, "Normative Positivism”, 421-2.

${ }^{42}$ Hart, Concept of Law, 154 [191]. 
¡Pero esto está siendo olvidado no por el invitado escéptico ante las reglas, sino por el anfitrión positivista suave! El sentido en que deben ser entendidas las reglas constitucionales que $(e . g)$ garantizan derechos no es una cuestión que esté en la periferia de nuestras prácticas jurídicas (quizás estaba en la periferia de las prácticas jurídicas de principios del siglo $\mathrm{XX}^{43}$ ). Los positivistas suaves están dando la bienvenida al escéptico ante las reglas en el núcleo mismo de nuestras prácticas jurídicas, obteniendo de este modo coherencia al alto precio de la deformación ${ }^{44}$. Ellos deben sostener que no hay respuesta jurídica a la pregunta de si las disposiciones constitucionales que protegen derechos (etc.) deben ser entendidas como haciendo referencia a la mejor teoría de los derechos fundamentales o la democracia, o a las intenciones del redactor o cosas por el estilo. En consecuencia, un juez que tiene que elegir entre estas interpretaciones no puede cometer un error de derecho. Y nótese que esta inestabilidad se comunica a todo el ordenamiento jurídico, al menos cuando la constitución hace depender la validez de las leyes de su respeto de esas disposiciones constitucionales.

Aquí debemos notar que esta conclusión escéptica es extraña viniendo de autores que creen pertenecer a una tradición positivista del derecho. En su momento explicaré cuál es el camino a través del cual, a partir de una visión positivista que reclamaba para el derecho autonomía de la moral, es posible llegar a las conclusiones escépticas a las que llegan los positivistas contemporáneos. Pero antes de eso debemos volver a los orígenes del positivismo jurídico, para apreciar la distancia que hay entre lo que hoy llamamos positivismo y eso que el positivismo en sus orígenes pretendía lograr.

\section{El positivismo como teoría del derecho moderno}

La versión inglesa del positivismo jurídico nació con la crítica de Bentham al common $l a w^{45}$. Esta crítica no estaba (sólo) dirigida contra el contenido del derecho inglés, como si Bentham hubiera creído que algunas de sus doctrinas o principios fueran contrarias al principio utilitarista (algunas veces "repugnaban a las finalidades de justicia” 46 y otras no, pero las objeciones de Bentham eran generales). Era una crítica a la concepción del derecho subyacente al common law. La radicalidad del argumento de Bentham

${ }^{43}$ Véase Atria, “La impureza de la aplicación del derecho”, 165-186.

${ }^{44}$ Lo mismo, en otras palabras, que Hart reprochaba a Kelsen (particularmente a su afirmación de que todas las normas jurídicas pueden reducirse a "normas primarias”: “distorsión como precio de la uniformidad”). Véase Hart, Concept of Law, 38 [50].

${ }^{45}$ Lo que desde luego no implica sostener que no hubo predecesores (como e.g. Hobbes, Leviathan, Ch 26 [217]: “la ley en general no es consejo, si una orden”). Véase Hart, “Demystification of the Law”, 27-28.

${ }^{46}$ Bentham, Rationale of Judicial Evidence, 204. 
residía en el hecho de que estaba introduciendo una concepción distinta, característicamente moderna del derecho, conforme a la cual el common law no era derecho o era a lo sumo una forma primitiva de derecho. Por eso tanto Bentham como sus oponentes utilizaban un lenguaje que a veces induce a pensar que la diferencia entre ellos era conceptual, que el debate era una "debate analítico entre los proponentes de la legislación y los defensores de la costumbre" ${ }^{47}$. Esto es, a mi juicio, un error. El debate no era analítico sino político, y para entenderlo debemos entender las diferencias entre una concepción premoderna y una moderna del derecho. Así entenderemos la conexión entre la idea central de la tradición positivista y la concepción moderna del derecho, y entenderemos por qué esa idea era (y sobretodo es) importante. Las consideraciones que siguen no son importantes por su sentido biográfico. De hecho, hoy hay poco desacuerdo en que el positivismo de Bentham es un positivismo de fundamentos éticos y no analíticos.

\section{Una concepción moderna del derecho}

El hecho que la primera formulación de la crítica de Bentham al common law apareciera impresa en 1776 es una coincidencia de profundo significado histórico. 1776 fue también el año en que la idea de la artificialidad y la contingencia de lo político irrumpió en la historia. Desde 1776 entendemos que la comunidad política es una condición artificial, no natural. Desde 1776 nuestras prácticas jurídicas y políticas están fundadas en "el reconocimiento de que la esfera política no nace automáticamente del hecho de la coexistencia”48; necesita estar artificialmente constituida.

Esta es la idea que los revolucionarios norteamericanos anunciaron al mundo en 1776: que los hombres estaban naturalmente dotados de derechos pero que también eran vulnerables, por lo que la protección de esos derechos justificaba que los hombres constituyeran gobiernos, reteniendo su derecho, si les parecía adecuado,

a reformarlo o abolirlo, a instituir un nuevo gobierno, y a organizar sus poderes de la forma en que a su juicio garantice mejor su seguridad y felicidad ${ }^{49}$.

\footnotetext{
${ }^{47}$ Waldron, “Custom Redeemed by Statute”, 95. Postema sostiene que las críticas de Bentham tenían un fundamento utilitarista, no analítico (Postema, Bentham and the Common Law, 296). Es decir, que Bentham formula una ontología buscando argumentos en su ataque al common law. Esto ha sido discutido por Moreso, quien cree que la relación es inversa: "la distinción benthamita entre entidades ficticias propiamente tales y entidades fabulosas es una distinción ontológica y lingüísticamente bien fundada”, y es esta distinción la que fundaría la crítica del common law (Moreso, La Teoría del Derecho de Bentham, 136).

${ }^{48}$ Arendt, On Revolution, 19 [19].

${ }^{49}$ Declaración de Independencia Norteamericana (1776).
} 
Como la asociación política se entendía ahora como artificial y contingente, el derecho requería un nuevo fundamento: la ley ya no podía ser entendida como el producto de una cuidadosa atención a la racionalidad intrínseca de las relaciones humanas; la ley no era algo dado, inmanente en la naturaleza de manera que el discurso jurídico debía considerarse como una forma de describirlo correctamente; la ley era la voluntad del soberano. El art. 1 del Código Civil Chileno no puede ser más explícito:

La ley es una declaración de la voluntad soberana que, manifestada en la forma prescrita por la constitución, manda, prohíbe o permite.

Es la ley la que manda prohíbe o permite. El derecho (las órdenes, prohibiciones o permisiones) fluyen de la ley; las reglas jurídicas ya no son regulae iuris romanas, que se limitaban a describir órdenes, prohibiciones o permisiones que existían con independencia de ellas (para facilitar su aplicación e identificación). Y esta ley manda, prohíbe o permite lo que el soberano desea mandar, prohibir o permitir. La ley, tal como la esfera política misma, es artificial, no natural. Una regla no es válida porque es razonable, sino porque es deseada por el soberano: auctoritas, non veritas, facit legem. En consecuencia, las normas jurídicas ya no pueden ser entendidas como el reporte de quien ha destinado su vida al estudio de la racionalidad intrínseca de las relaciones humanas, ellas son la ley en el sentido que ellas constituyen el derecho. No hay razón intrínseca en la legislación ${ }^{50}$.

\footnotetext{
${ }^{50}$ La visión del derecho premoderno que subyace a esta sección está fuertemente influida por Detmold, “Law as Practical Reason”. Para la idea de regulae iuris romana, véase Digesto 50.17.1.pr: "una regla es algo que describe brevemente una cosa. El derecho no surge de la regla, sino la regla del derecho”. He discutido esta idea de las reglas en Atria, Law and Legal Reasoning, 150-159. Por supuesto no estoy diciendo que el derecho fue no-contingente hasta el 3 de julio de 1776 y comenzó a ser entendido como contingente el 4 de julio de ese año. Las prácticas jurídicas pre-revolucionarias habían comenzado a entender, producto del absolutismo, al derecho como órdenes del soberano. Pero que en la práctica jurídica comiencen a ser discernibles nuevas tendencias no equivale a que la práctica jurídica se conciba a sí misma de la manera que “corresponde” a esas tendencias. La evolución es más lenta: usualmente factores extraños al derecho impulsan ciertas formas jurídicas novedosas, que existen por un tiempo de modo no teorizado en el contexto de un sistema a cuyos principios fundamentales hacen excepción. Al cabo de un tiempo esas excepciones comienzan a ser teorizadas, hasta que ellas dejan de ser excepciones y comienzan a configurar los aspectos centrales de una nueva forma de comprender el derecho. Esa nueva forma inicialmente es defendida por elementos marginales de la cultura jurídica, pero en algún momento (si la transición ha de ser exitosa) se hace dominante en la academia y comienza a dominar el modo en el cual los futuros jueces y abogados son educados (este es el momento en que esa nueva visión del derecho alcanza lo que más adelante llamaré su "mayoría de edad"). Con el tiempo, estas ideas dominantes en la academia se hacen dominantes en la práctica en general (por supuesto, no estoy ofreciendo esto como una gran teoría de la evolución del derecho, sino como una manera de comprender el modo en que las maneras de comprender el derecho evolucionan. Lo que quiero enfatizar es que el impacto del hecho político en los modos de comprensión de los participantes está mediado, al menos en las
} 
Como las leyes, que pueden ser creadas a voluntad por el soberano, constituyen y no describen el derecho, éste se hace contingente: "tres palabras rectificadoras del legislador son suficientes para transformar bibliotecas enteras en escombros”, en la radical frase de von Kirchmann ${ }^{51}$. Era necesaria entonces una comprensión radicalmente distinta de la autoridad del derecho y del razonamiento jurídico.

Esta nueva comprensión tenía que abandonar (o al menos degradar a un rol subordinado) la noción de la razón "artificial" del derecho, que era una forma especial de conocimiento práctico administrado por abogados y jueces (quienes de hecho lo usaban, al menos según Bentham, para fomentar sus "siniestros intereses" de grupo ${ }^{52}$ ). Para abandonarla, tenía que enfatizar la naturaleza positiva del derecho, el hecho de que la ley debía ser obedecida no porque fuera intrínsecamente razonable (i.e. porque describiera correctamente la racionalidad intrínseca de las relaciones humanas), sino porque descansaba en la autoridad del soberano. Por supuesto, esto hipotecaba cualquier seguridad de la corrección material del derecho, y por esta razón la consigna de un buen ciudadano bajo el gobierno de las leyes era "obedece puntualmente, censura libremente" 53 .

Esta comprensión moderna del derecho estaba en directa oposición a la tradicional auto-comprensión del common law. Según esta última, el derecho era una especial combinación de lo universal y lo particular. El derecho era universal en la medida que podía reconducirse a los principios universales de justicia y razón. En este sentido el derecho se entendía a sí mismo como natural: el derecho era el producto de la razón en la historia, i.e. en tiempo y lugar.

Aquí la universalidad de los principios de la razón se unía a lo particular de las doctrinas del common law: si el derecho era el producto de la razón natural, universal, ¿ cómo podía entenderse que fuera distinto en cada país? Los principios básicos del derecho natural podían ser descubiertos a través de la razón, y de esos principios otros principios podían ser deducidos. Pero

culturas jurídicas donde el derecho es un objeto de reflexión y los participantes principales de las prácticas jurídicas reciben educación formal, por la teorización sobre la prácticas. Véase, para un ejemplo, la interpretación de la evolución seguida por el derecho norteamericano durante el siglo XX narrada por en Ackerman, Reconstructing American Law).

51 Von Kirchmann, La Jurisprudencia no es Ciencia, 29. Algo de esta idea de von Kirchmann aparece cuando un estudiante va a estudiar derecho al extranjero, en la pregunta indefectible del lego: “¿de qué sirve, si las leyes son diversas?”. En su momento deberemos explicar qué es lo que el lego y von Kirchmann ignoran. La frase de von Kirchmann, como sabe cualquier abogado, no es falsa sino exagerada.

52 Bentham, Rationale of Judicial Evidence, 10-11.

${ }^{53}$ Bentham, Fragment, 230. 
(algunas de) las reglas y doctrinas del common law eran propias de los ingleses, y por esa razón no podían ser racionalmente deducidas de los principios universales. ¿Cómo podían justificarse? ¿Cómo podía un abogado inglés justificar racionalmente el contenido del common law ante un abogado veneciano, cuando ambos discrepaban, si ninguno de ellos podía alegar que el derecho de su país se deducía racionalmente de los primeros principios de la razón práctica? Ambos derechos, el inglés y el veneciano, eran de hecho inconmensurables, porque ambos eran igualmente particulares. El abogado inglés y el veneciano, sin embargo, podían

recurrir al último refugio del científico social cuando se enfrenta a casos de inconmensurabilidad: podían cuantificar. Si las leyes de Inglaterra eran efectivamente más antiguas que las de Venecia y se habían aplicado continuamente por mayor tiempo, podía concluirse que más hombres, durante más años y en más ocasiones, habían testificado silenciosamente en su favor ${ }^{54}$.

Esto explica la importancia del derecho consuetudinario. El valor de la costumbre como fuente del derecho radicaba en que ella era el precipitado de experiencia inmemorial. El common law era el resultado de incontables generaciones de ingleses que habían llegado a la conclusión de que ésa era la mejor manera de entender las exigencias de la razón natural aplicadas a las especiales circunstancias de los ingleses:

No podemos dar la 'razón' por la que una costumbre es buena o mala; sólo podemos decir 'hay razón para creer' que es buena (porque se ha mantenido) o mala (porque se abandonó). Esto es lo que Edmund Burke [...] llamaría razonamiento 'prescriptivo' o 'presuntivo'. Como una costumbre o una institución en particular tenía una pretensión 'prescriptiva' -i.e. ya estaba en uso- eso contaba como una 'presunción' a favor de ella; presumimos que se ha considerado que funciona bien. A mayor tiempo de existencia de la costumbre, mayor la presunción a su favor ${ }^{55}$.

Por esto las reglas jurídicas y la doctrina no eran entendidas en el sentido normativo en que las entendemos hoy: ellas no constituían el derecho, sino que eran reglas de experiencia (rules of thumb), vale decir, no eran normas sino indicios que permitían determinar lo que era el derecho (i.e. la mejor comprensión de los principios universales del derecho natural aplicados a las circunstancias de los ingleses) con independencia de ellas ${ }^{56}$. Si de acuerdo a una costumbre inmemorial $\mathrm{X}$ era la ley, esto se debía a que $\mathrm{X}$ era, de acuerdo a la razón natural, apropiada para Inglaterra como lo testificaban

\footnotetext{
${ }^{54}$ Pocock, The Machiavellian Moment, 15-16.

55 ibíd., 15].

${ }^{56}$ La idea de reglas que en realidad son proposiciones normativas, esto es, descripciones de lo que el derecho es con independencia de las reglas, es (aunque no en estos términos) uno de los temas discutidos por Stein, Regulae Juris.
} 
todos aquellos que a través de su comportamiento habían contribuido en el pasado a la formación y mantención de la costumbre, y no porque la costumbre haya creado una norma jurídica que antes no existía. La regla o doctrina era un reporte (de jueces anteriores en el caso de los precedentes, de legos en el caso de la costumbre, del Parlamento en el caso de una ley creada por el Parlamento) sobre lo que se consideraba razonable en esas circunstancias. La ley se entendía intrínsecamente vinculada a una razón ${ }^{57}$.

Así se explica la famosa frase de Coke

Que en muchos casos, el common law controla las leyes del Parlamento, y en algunas oportunidades resuelve que son nulas: puesto que cuando una ley del Parlamento es contraria al derecho común y a la razón [common right and reason], o repugnante, o imposible de realizar, el common law la controlará, y la declarará nula ${ }^{58}$.

Aunque en cierto modo el common law, al declarar nulas ciertas leyes, estaba limitando la autoridad del parlamento, la importancia de la tesis de Coke radica en el hecho de que, como el common law no debía su autoridad al parlamento (sino al contrario) era la actividad de éste lo que debía ser entendido a la luz de aquél. En otras palabras, la autoridad del Parlamento era entendida como hoy entenderíamos la de un tribunal supremo: ella se fundaba en que sus decisiones reflejan el derecho previamente aplicable, aun cuando ellas pueden gozar de la autoridad de cosa juzgada aun cuando fueran equivocadas ${ }^{59}$. Ahora bien, como lo que la razón requería en esas circunstancias no era deducible de los primeros principios de la razón natural sino aprendido a través de la experiencia inmemorial, el common law era altamente técnico:

El conocimiento de casos concretos y el discernimiento de cómo han de ser aplicados en ellos los principios es un proceso intelectual totalmente diferente del conocimiento de los principios y la deducción de sus consecuencias lógicas. De hecho, apenas puede ser considerado un proceso intelectual; es sólo materia de prueba y error, ya que lo buena que es una norma consuetudinaria no se prueba con su verificación racional, sino con el simple hecho que se mantiene en uso. Es por ello que el conocimiento de un abogado no se puede reducir al conocimiento de algunos principios y sus consecuencias; el conocimiento ha de versar sobre qué principios se mantienen, y cuales son las consecuencias técnicas de su mantención más que sus consecuencias lógicas ${ }^{60}$.

Este conocimiento técnico era el lenguaje usado para entender el derecho. Las categorías y conceptos técnicos eran receptáculos de experiencias

\footnotetext{
${ }^{57}$ Detmold, “Law as Practical Reason”, 36-40.

${ }^{58}$ Coke, Dr. Bonham's Case, 275.

${ }^{59}$ Detmold, “Law as practical reason”, 41-50.

${ }^{60}$ Pocock, The Machiavellian Moment, 16.
} 
antiguas, y como tales, las nuevas reglas o la doctrina debían entenderse y aplicarse a través de ellas, en términos de ellas. Por eso la pretensión de Coke, al decir que el common law podía declarar nulas leyes del Parlamento, no ha de ser entendida como una forma de limitar la autoridad legislativa del Parlamento (Coke, entonces, no es un antecesor del Juez Marshall en Marbury v. Madison), sino como la consecuencia obvia del hecho de que lo que el Parlamento hace cuando dicta una ley es intentar determinar qué es lo razonable en las circunstancias. Como ésa es la manera en que debemos entender lo que el Parlamento hace, es posible que el Parlamento yerre, en el mismo sentido en que una decisión judicial puede errar si no refleja las leyes aplicables ${ }^{61}$; tal como en el caso de un tribunal, sin embargo, esto no significa que una decisión por ser errada sea inválida. Tal como una juez qua juez debe entender que su decisión debe reflejar la ley aplicable de manera que si no lo hace es errónea, si una ley del Parlamento era contraria al derecho común y la razón, podía entonces asumirse que el Parlamento realmente no quería que se transformara en derecho. Coke cita a Herle:

Algunas leyes son establecidas contra el Derecho Común y el derecho, de manera que quienes las crearon no las habrían puesto en vigor ${ }^{62}$.

Por lo tanto, cuando el common law "declara nula una ley del Parlamento" no está imponiendo a la potestad legislativa del Parlamento un límite externo, sino entendiendo lo que ésta ha producido de acuerdo a la finalidad que el Parlamento debe haber tenido en mente al legislar. Para usar el ejemplo de J.S. Mill, el Almanaque Náutico puede servir como guía para el marino porque contiene información útil para éste. La información es útil, porque facilita el conocimiento de algo (i.e. la posición de las estrellas) que es como es con independencia del almanaque. Parafraseando a D. 50.17.1.pr: no es que la posición de las estrellas fluya del almanaque, el almanaque fluye de la posición de las estrellas ${ }^{63}$; el almanaque no vale en sus propios términos, vale porque en él se contiene una correcta descripción de la posición de las estrellas tal que permite a los marinos calcular su latitud. El almanaque, como la regla romana, no tiene fuerza normativa propia: es un mecanismo que permite ahorrar tiempo (y esfuerzo, etc). Por eso si en el almanaque hay un error ${ }^{64}$ no tendría sentido decir que sus autores han sobre-

${ }^{61}$ Detmold, "Law as Practical Reason”.

${ }^{62}$ Sheppard, The Selected Writings of Sir Edward Coke, 275.

${ }^{63}$ Véase Mill, Utilitarianism, Ch 2 [73]: “Nadie argumenta que el arte de la navegación no se funda en la astronomía, porque los marinos no pueden esperar a calcular el Almanaque Náutico. Siendo criaturas racionales, se adentran en el mar cuando ya lo tienen calculado”.

${ }^{64} \mathrm{O}$, como imagina J.C.C. Smart, si el movimiento del sol, la luna y los planetas fuera muy similar, como lo es hoy, pero en algunas ocasiones hubiera irregularidades particulares, 
pasado los límites substantivos de su autoridad. Lo que diríamos es lo que Herle dijo según la cita de Coke, que de haber sabido lo que ahora sabemos, no habrían hecho o dicho lo que hicieron o dijeron

Como sostiene correctamente Detmold, nuestros ojos modernos no deben llevarnos a atribuir a Coke más de lo que debemos ${ }^{65}$. En particular es importante destacar que la tesis de Coke sobre la razón artificial del derecho no es una tesis sobre la extensión de los poderes institucionales de los jueces en relación a los del Parlamento ${ }^{66}$. El punto aquí no consiste en determinar hasta dónde llega la obligación del juez de aplicar las leyes del Parlamento, sino la forma en que se entiende y justifica la autoridad no sólo del Parlamento y del juez, sino del derecho en general. Es así como Blackstone compartía la comprensión de la autoridad del derecho de Coke pero eso no le impidió reconocer supremacía al Parlamento:

Sé que es ampliamente aceptado que las leyes del Parlamento contrarias a la razón son nulas. Pero si el Parlamento establece de manera positiva que un acto irracional debe hacerse, no conozco potestad alguna dentro de la Constitución que esté facultada para controlarlo ${ }^{67}$.

En términos estrictos, la pretensión de Coke según la cual el derecho común puede declarar las leyes establecidas por el Parlamento nulas si son contrarias a la ley común y la razón es compatible con la pretensión de Blackstone de que no hay autoridad competente sobre el Parlamento que pueda efectuar tal declaración. Para hacerlo basta con entender que el "puede" de Coke no hace referencia a una potestad institucionalmente reconocida sino al status del common law en relación al derecho legislado (o a decisiones judiciales particulares, de hecho), y que lo que Blackstone enfatiza no es que el parlamento sea infalible sino que sus decisiones son definitivas. La cuestión es más clara si se reemplaza la expresión “derecho común” por "ley” en la frase de Coke y se aprecia el sinsentido que resulta. La frase "la ley controla las leyes del Parlamento, y en algunas oportunidades resuelve que son nulas” sería absurda no porque sea contraria a alguna regla secundaria de adjudicación, sino porque la ley, creada por el legislador, no puede constituir un punto de vista desde el cual controlar las decisiones del legislador. La tesis de Coke es que el common law sí constituye un punto de vista que

de manera que los cálculos del almanaque fuesen correctos en el 99\% de los casos. Véase la discusión sobre las reglas de experiencia (rules of thumb) en Smart, "Utilitarianism”, 176-183 [255-265].

${ }^{65}$ Detmold, “Law as Practical Reason”, 445.

${ }^{66}$ ibíd., 449ss.

${ }^{67}$ Commentaries on the Laws of England (ed. Tucker), Philadelphia, 1808, vol. I, secc. 3.3. 
lo permite. O, para decirlo de otro modo, una cosa es aceptar que, en virtud del tipo de autoridad que detenta, las decisiones del Parlamento (o los datos relevantes en una copia del almanaque) puedan ser erróneas en sus propios términos y una distinta es creer que un juez (o un marinero en el mar) está en una posición correcta para identificar el error y actuar sobre la base de esa identificación. De esta manera, puede ser perfectamente razonable que los jueces no tengan la autoridad para declarar las leyes del Parlamento nulas (¡aún cuando puedan serlo!), así como puede ser sensato que el policía no tenga la potestad de declarar nulas las decisiones del juez cuando crea que son incorrectas (aunque puedan serlo), o que el armador ordene a sus capitanes que en el mar sigan el almanaque aun cuando crean que han encontrado en él un error (aunque pueda haberlo). Para esto basta notar que cuando el juez, el policía o el capitán creen haber encontrado una decisión errada del legislador, del juez o del redactor del almanaque es también posible que la decisión sea correcta y que sean ellos los equivocados. Si esta segunda situación es más probable que la primera, puede ser sensato que, como cuestión de ordenación institucional, se le niegue al juez, al policía o al capitán la potestad de actuar sobre la base de su creencia sobre la corrección o incorrección de la decisión del legislador, del juez o del redactor del almanaque.

\section{La razón artificial del derecho}

Se sigue de la comprensión pre-moderna del derecho que las leyes y la doctrina deben ser entendidas a través de los conceptos y categorías del common law, no porque el parlamento esté sometido al common law en el sentido en el que hoy, por ejemplo, la administración está sometida a la ley (sus actos pueden ser invalidados cuando son ilegales a juicio del juez respectivo), sino porque lo que el parlamento hace es entendido como "secondguessing" al common law. Por lo mismo, éste no puede ser modificado por aquél. De acuerdo a lo dicho, aun cuando se acepte la autoridad definitiva del Parlamento en el sentido de que lo que el parlamento ha decidido no puede, por razones institucionales, ser anulado por otra autoridad (como en Blackstone), lo que el Parlamento establece debe ser entendido a través de

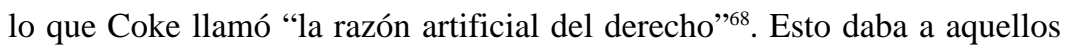
que conocían el derecho, a los abogados y jueces, una especial influencia a la que se encontraba sujeta cualquier iniciativa de reforma jurídica.

Esta pretensión de la profesión jurídica, de que el derecho debía ser entendido de acuerdo a sus conceptos y categorías tradicionales, que a su

${ }^{68}$ Coke, Prohibitions del Roy, 275. 
vez eran inmunes a la modificación voluntaria y conciente, fue uno de los principales blancos de la crítica de Bentham. La naturaleza técnica del common law, que de acuerdo a la visión tradicional estaba necesariamente unida al fundamento de su autoridad en la fusión de los principios universales de la razón y las circunstancias particulares de cada nación como habían sido entendidas por incontables generaciones, era para Bentham una falsa pretensión, que buscaba asegurar a la profesión legal, a "Judge \& Co.” como los denominaba Bentham, una manera especialmente efectiva de proteger sus "siniestros intereses" ${ }^{\prime \prime}$. Como Bentham sostenía, al justificar ante los ciudadanos de Estados Unidos las ventajas de la codificación:

Junto a este espurio tipo de leyes, de cuya interpretación [...] obtienen su ganancia los abogados, se presenta una cantidad significativa de argumentaciones, dadas bajo el nombre de razones [...] La mayor parte de estas razones se denomina, para utilizar el nombre que ellos utilizan cuando hablan entre sí, técnicas. Pero siempre que junto a la palabra razón ustedes vean la palabra técnica como una explicación de ella, reemplacen o substituyan -porque lo pueden hacer con escaso peligro de equivocarse- las palabras absurda y deshonesta. Absurda en cuanto a su naturaleza, deshonesta en cuanto a su causa ${ }^{70}$.

Es interesante resaltar que para Bentham el problema no era que los jueces tuvieran discreción; Bentham no era partidario del giro adoptado por el pensamiento jurídico continental hacia lo que Hart llamaría el vicio conocido por la teoría del derecho como "formalismo" de Bentham estaban dirigidas contra la falta de certeza y la arbitrariedad que el common law permitía a los jueces, aunque nosotros agregaremos en su momento a estas consideraciones el hecho que el common law, como Bentham lo entendía, hacía imposible el ideal moderno de autogobierno ${ }^{72}$. El utilitarismo de Bentham le permitía (incluso, podría uno decir, le exigía) reservar para los jueces el poder de introducir excepciones a las reglas ge-

${ }^{69}$ vid. por ejemplo Bentham, Justice and Codification Petitions, 449.

${ }^{70}$ Bentham, Bentham to US Citizens, 497-8.

${ }^{71}$ Hart, Concept of Law, 129 [161].

72 Aunque parece haber un eco de esta idea en la afirmación de Bentham de que el common law es hecho por jueces, "obreros clandestinos, siempre trabajando, siempre negando lo que han hecho cuando ya lo han hecho” Bentham, Rationale of Judicial Evidence, 309. Véase también Bentham, Bentham to US Citizens, 284: “¿Reglas? si, digo: ¿Reglas jurídicas? No. Estas reglas, ¿por quién están hechas? Puede ser posible responder a esta pregunta; pero lo que es no sólo siempre posible, sino adicionalmente verdadero, es que la o las personas que hacen estas reglas [...] es o son en cada caso, sin excepción, una persona o personas que, respecto de cualquier participación que haya o hayan tenido, o se suponga que haya o hayan tenido, en la creación de esas reglas, carecen de cualquier título para crear derecho o participar en la creación de derecho". O, como dice poco después del common law, "cada pedazo de él hecho por individuos, ninguno de los cuales ni siquiera pretende tener derecho a crear derecho” (ibíd., 289). 
nerales cuando el principio de utilidad y los antecedentes de cada caso en particular lo demandaran ${ }^{73}$. Su desprecio no era hacia un sistema en que los jueces tuvieran discreción en casos de este tipo, sino por un sistema que era, por razones que discutiremos más abajo, arbitrario hasta la perfección.

Todos los problemas del common law podían ser resueltos por la legislación -si sólo el derecho fuera entendido como la voluntad del soberano y no como el desenvolvimiento de la razón natural de acuerdo a lo que había resultado ser útil al pueblo inglés en la forma que lo han entendido los precedentes y la costumbre y declarado ocasiones el Parlamento; si sólo la práctica "tan extensamente practicada y familiar para cualquiera" de atribuir "un nuevo sentido a las palabras, hasta entonces nunca imaginado"74 fuera reemplazada por una práctica igualmente desarrollada de subordinación judicial al derecho legislado! El positivismo jurídico de Bentham debe ser entendido como su contribución a la creación y la mantención de una práctica “positivista” en este sentido. El common law era la enfermedad, el positivismo la cura.

En conclusión, el positivismo jurídico nació enfatizando la idea de que el derecho era un producto humano, y por tanto era un instrumento de la política. Negaba la existencia de una "razón artificial” especial del derecho, una clase de razón que se encontraba a disposición preferencial de jueces y abogados, y que sujetaba cualquier agenda reformista a su opinión de lo que era "razonable”. La ironía, como hemos visto, es que esta preocupación original de los positivistas jurídicos de crear un ethos de respeto a la autoridad del derecho legislado en tanto legislado ha sido completamente abandonada por los positivistas contemporáneos: ambas partes de la disputa de familia mencionada al principio se apresuran a negar cualquier conexión entre su comprensión del positivismo jurídico y cualquier forma particular de adjudicación. El siguiente comentario, hecho por un positivista "incluyente”, es bastante representativo:

la idea de que el positivismo jurídico llama a una adhesión esclavizante a la letra de las normas en cualquier sistema jurídico particular [es falsa]. De hecho, el positivismo judicial no prescribe ningún método particular de adjudicación ${ }^{75}$.

${ }^{73}$ Bentham llamaba a esto el "poder suspensivo”. Véase Bentham, Draught of a Code, 313.

${ }^{74}$ Bentham, Rationale of Judicial Evidence, 487-8.

${ }^{75}$ Kramer, In Defense of Legal Positivism, 114. Me imagino que uno podría eliminar, salva veritatis, el retórico “esclavizante”. En realidad, la última parte de la cita de Kramer muestra que también podríamos omitir la expresión "la letra de” sin cambio de sentido de la frase. Creo que puede mostrarse que esta pretensión es, en el sentido relevante, totalmente incorrecta: véase Atria, Law and Legal Reasoning, 169-171. Véase también más abajo, el texto que acompaña las nn. 102-107. 
Ya hemos visto que la razón por la que los positivistas contemporáneos están tan ansiosos de negar que el positivismo que ellos defienden tiene algo que ver con alguna doctrina sobre la adjudicación es que ellos se ven a sí mismos como participantes de una empresa significativamente diversa de la que ocupaba a Bentham. Si tienen simpatía por el proyecto benthamita, distinguirán entre Bentham como expositor y como censor de las concepciones del derecho. El positivismo como teoría del derecho se formula desde la posición del expositor (positivismo “metodológico”, en términos de Bobbio), la defensa de la autoridad del derecho legislado es propia del censor (positivismo “ideológico”). Si no la tienen, lo acusan de incoherencia:

El positivismo jurídico formula una pretensión conceptual o analítica sobre el derecho, y esa pretensión no debe ser confundida con intereses programáticos o normativos que ciertos positivistas, especialmente Bentham, pueden haber tenido. Irónicamente, sostener otra cosa es incluir, dentro del concepto de derecho, una teoría normativa particular del derecho; es infundir moralidad, o cómo el derecho debería ser, al concepto de derecho. En otras palabras, el argumento de atribuir ciertos principios al positivismo como consecuencia de la idea normativa de derecho del positivista comete el mismo error que con tanto énfasis el positivismo pretende identificar y rectificar ${ }^{76}$.

Por razones que serán evidentes a medida en que vayamos progresando, no nos será posible evaluar la justicia de esta crítica contra el positivismo jurídico en su modalidad "ética” (“ideológica”) sin considerar con cierto detalle el análisis de Bentham de las contradicciones del common law y lo que llamaré el “ciclo de la adjudicación”. Esto nos proveerá una clave que nos permitirá comprender tanto el predicamento actual de la teoría general del derecho contemporánea como las características generales de una salida de él.

\section{El ciclo de la adjudicación}

¿Podemos decir algo en defensa de Bentham contra la objeción de Coleman? Esta cuestión ha sido discutida por J. Waldron, y será útil considerar la versión que para responderla defiende Waldron de positivismo ético (él lo llama "normativo") ${ }^{77}$. Waldron distingue entre el uso "al por mayor” y "al por menor" de argumentos morales: el positivismo ético usa el argumento moral al por mayor, para justificar la dignidad de la legislación y la sujeción de los jueces al derecho legislado, pero excluye el argumento moral al por menor, al momento de identificar reglas particulares de derecho o de establecer el contenido preciso del deber jurídico del juez de decidir casos

\footnotetext{
${ }^{76}$ Coleman, "Negative and Positive Positivism”, 34.

${ }^{77}$ Waldron, “Normative Positivism”, 413-422.
} 
particulares de acuerdo a la ley ${ }^{78}$. Como no permite argumentos morales al por menor, el positivismo de Waldron no cometería el mismo error que con tanto énfasis el positivismo en general pretende identificar y rectificar ${ }^{79}$.

A mi juicio, el positivismo ético de Waldron no se dirige a la fuente del problema, y al negar la relevancia de las consideraciones morales en el nivel al por menor simplemente lo reproduce. Es por ello que una forma razonable de positivismo ético (como de hecho, sostendré, la versión de Bentham) no necesariamente excluye toda forma de argumentación moral al por menor. Es más, el problema central para el positivismo ético es cómo permitir una forma de argumentación legal que pueda aceptar el argumento moral al por menor sin disolver la argumentación legal en argumentación moral simpliciter.

La cuestión de cómo este problema central puede ser resuelto ha de quedar para otra ocasión ${ }^{80}$, porque es el problema de formular una distinción entre jurisdicción y legislación que entienda que la primera aplica la segunda sin reducir por eso el juez a la función de "boca de la ley”. Quiero explicar ahora por qué la de Waldron no es una opción viable: ¿Por qué no es suficiente entender que el positivismo ideológico (o ético, o normativo) prescribe, basado en argumentos morales (al por mayor) sobre lo que el derecho es y el valor de gobernarse a través del derecho, una forma excluyente (“dura”) de positivismo? La respuesta es nuevamente entregada por el mismo Bentham, y G Postema la ha llamado "la paradoja de la inflexibilidad"81 (como en términos estrictos no se trata de una paradoja, y si lo fuera sería “de la flexibilidad” tanto como de la inflexibilidad, me referiré a ella como el “ciclo de la adjudicación”).

El péndulo del common law

El ciclo de adjudicación es la respuesta de Postema a una aparente contradicción en la crítica de Bentham al common law. En efecto, Bentham parece sostener

que el common law es excesivamente rígido y también arbitrariamente flexible e indeterminado, que la adjudicación del common law involucra tanto la imitación mecánica como la manipulación judicial de ficciones, las fórmulas abstractas de 'derecho natural', y otras parecidas, sujetas exclusivamente al capricho judicial y los intereses siniestros ${ }^{82}$.

\footnotetext{
${ }^{78}$ ibíd., 415-418.

${ }^{79}$ Supra n. 76.

${ }^{80}$ Véase Atria, “Jurisdicción e independencia judicial”.

${ }^{81}$ Postema, Bentham and the Common Law, 279-286.

82 ibíd., 279-280.
} 
Según Postema, la contradicción no es de Bentham, sino del common $l a w^{83}$, cuyo gran problema era que no podía proveer un equilibrio sostenible entre (para decirlo con palabras de Hart) "la necesidad de reglas ciertas [...] y la necesidad de dejar abiertas [...] cuestiones que sólo pueden ser apreciadas y resueltas correctamente cuando surgen" ${ }^{\text {}}$. Incapaz de conciliar estas demandas en conflicto, el common law "estaba condenado a oscilar, como un péndulo, entre los polos opuestos de arbitrariedad y rigidez" ${ }^{\text {. }}$.

Postema describe el ciclo que se desarrolla en tres etapas: en la primera etapa, caracterizada por decisiones judiciales sin regla de stare decisis, el common law es arbitrario: cada juez decide de acuerdo a sus apreciaciones cada caso. Como no hay regla de precedentes, las decisiones judiciales "no pueden comenzar a servir el fin de la seguridad que es la función básica del derecho" ${ }^{\$ 6}$. Como reacción a la arbitrariedad de esta primera etapa, en la segunda se ha introducido una regla de stare decisis, de acuerdo a la cual las decisiones pasadas son vinculantes para los jueces actuales. El problema del stare decisis es que rigidaza la adjudicación, causando lo que Bentham llamó el "carácter no acomodaticio" (unaccommodatingnes) del common law. Incluso las reglas que son razonables y justificadas desde el punto de vista de la utilidad "o quedan bajo la marca o la sobrepasan"87, son, para decirlo en un lenguaje familiar, sobre-inclusivas o sub-inclusivas ${ }^{88}$. Como los jueces y la profesión jurídica, que han conocido (en la primera etapa) los riesgos de la arbitrariedad judicial, aprecian y valoran la finalidad de certeza que persigue la regla de stare decisis, ellos aceptan que las reglas no sean acomodaticias como precio, y están entonces dispuestos a ignorar la injusticia que ellas por eso causan en algunos casos $^{89}$. Esto explica "la dureza de corazón que es una especie de enfermedad endémica de los abogados" ${ }^{\text {"90 }}$. Las mismas razones que provocaron el movimiento desde la primera etapa a la segunda, es decir, las que justificaron la adopción de la regla de stare decisis, hacen que los profesionales del derecho se contenten con "hacer parcialmente el

${ }^{83}$ ibíd., 280.

${ }^{84}$ Hart, Concept of Law, 130 [162].

${ }^{85}$ Postema, Bentham and the Common Law, 280.

${ }^{86}$ Este es el momento que Bentham denominaba como del “derecho bárbaro”. Véanse los tres estados “de la sociedad humana respecto del derecho”, más abajo, como epígrafe de la siguiente sección.

${ }^{87}$ Bentham, Of Laws in General, cap. 12n1.

${ }^{88}$ En la terminología de Schauer, Playing by the Rules, 31-34[89-92].

${ }^{89}$ Estos son los casos que Schauer llama “recalcitrantes”: véase ibíd., 39-47 [97-106].

${ }^{90}$ Bentham, Of Laws in General, cap. 12n1. 
mal”, porque lo hacen motivados por mantener "ese bien universal que consiste en la adhesión constante a reglas preestablecidas”91.

Ahora bien, al hacer parcialmente el mal los abogados y los jueces se acostumbran a "acumular [...] sufrimientos sobre las cabezas de quienes no los merecen, a sabiendas de que no los merecen"92. Pero, como Rudolf von Ihering notó en la clásica sección 50 del libro II de El Espíritu del Derecho Romano, el mal parcial que los jueces hacen en casos particulares puede ser altamente visible, mientras que la contribución que la resolución de cada caso conforme a una regla hace al bien universal de la adhesión constante a esas reglas es mucho menos notoria, aunque no menos real:

Todo el mundo hace constar sus defectos [del formalismo] y nadie se fija en sus beneficios, que son puramente negativos, es decir, impiden que se produzca el mal. Un solo caso que haga resaltar los inconvenientes de la forma, como por ejemplo un testamento declarado nulo, un pleito perdido por un vicio o descuido de la forma, hieren y se hacen notar más vivamente que millares de casos en que, para el curso ordinario de las cosas, la forma ha cumplido su misión tutelar ${ }^{93}$.

La “dureza de corazón”, que Bentham observa como el mal endémico de los abogados, es aceptada como el acompañante necesario de la forma. Esa injusticia se justifica porque, como también dice Ihering, “enemiga jurada de la arbitrariedad, la forma es la hermana gemela de la libertad"94. Esta justificación será particularmente poderosa a los ojos de quienes tengan vivo el recuerdo de la primera etapa del ciclo. Pero a medida que ese recuerdo disminuya y la regla de stare decisis se convierta en ortodoxia y empiece a ser obvia, el logro valioso que ella representaba perderá urgencia. Entonces la presión pública por evitar acumular sufrimientos sobre las cabezas de quienes no los merecen se vuelve progresivamente más fuerte, y las cosas están dadas para alcanzar la tercera etapa del ciclo:

Cuando finalmente los ojos del público se abran, el mal que ha sido el resultado de seguir cada [juez] los pasos del otro en casos de poca importancia se ha vuelto tan palpable y groseramente problemático -decretando la impunidad, por ejemplo, de un asesino porque alguna palabra ha sido mal escrita o no se escribió como debía- cuando las cosas han llegado hasta este punto, no sólo le será permitido al juez apartarse del precedente sino que cuando lo haga será aplaudido ${ }^{95}$.

91 ibíd.

${ }^{92}$ En palabras de Bentham, ya que la frase es difícil de traducir: se acostumbran "to heap [...] miseries on the head of those by whom [they] know them to be unmerited" (ibíd).

${ }_{93}$ Ihering, Espíritu del Derecho Romano, 647 (L. 2, §50). Ésta es la razón por la cual "nada de pasmoso es, por lo tanto, que el juicio del ignorante se muestre tan hostil al formalismo" (Ihering, Espíritu del Derecho Romano, 647 (L. 2, §50.1).

${ }_{94}^{4}$ Ihering, Espíritu del Derecho Romano, 641 (L. 2, §50).

${ }^{95}$ Bentham, Justice and Codification Petitions, 478 
En este momento el péndulo vuelve perversamente a la situación original, aunque agravada: ahora el sistema no sólo es arbitrario sino arbitrario hasta la perfección, porque el juez ahora puede, en cualquier caso,

sin el peligro de un castigo del derecho y sin siquiera temor a la censura de la opinión pública, [...] dar la razón al demandante o al demandado, de acuerdo a lo que él quiera ${ }^{96}$.

Este es el principio de la "doble fuente", con el cual Bentham se burla de la idea de Lord Mansfield de que el common law se hace puro a sí mismo bebiendo de la fuente de la justicia ${ }^{97}$. Ahora el juez puede beber "a placer" tanto de la fuente del stare decisis como de la fuente de la discrecionalidad. El juez se encuentra "en perfecta libertad para otorgar o negar impunidad al asesino, a placer: si se la niega, discrecionalidad es su palabra; si la otorga, stare decisis" ${ }^{\prime \prime 8}$.

\section{El positivismo jurídico y el ciclo de la adjudicación}

Para Bentham, el problema era el common law, y sólo mediante una reforma jurídica a gran escala podía ser solucionado. Esta reforma era la codificación $n^{99}$. Él creía que el derecho legislado estaba libre de este problema, porque a diferencia de las decisiones judiciales las reglas legisladas podían ser "lo suficientemente amplias en alcance" y "lo suficientemente precisas en su formulación" como para evitar o al menos reducir dramáticamente los casos recalcitrantes ${ }^{100}$. Postema generaliza y provee una explicación estructural para la ocurrencia del ciclo:

Aun si la ley fuera relativamente justa, el problema reside en que el juez -como no hay otra fuente válida de reglas jurídicas- está cargado tanto con las tarea de proteger la seguridad y certeza del derecho como al mismo tiempo mantener cierta sensibilidad a las demandas de justicia y utilidad particular de cada caso ${ }^{101}$.

Nótese cómo la tensión fundamental que está detrás del ciclo de la adjudicación se presenta también en el positivismo analítico. Por supuesto, ya sabemos que los positivistas analíticos reclaman que el positivismo no supone ni implica recomendación alguna sobre la adjudicación. Pero a

\footnotetext{
96 ibíd.

97 "Una ley raramente se refiere a todos los casos, y por eso el common law, que se hace a sí mismo puro bebiendo de la fuente de la justicia, es por esta razón superior a una ley del Parlamento” (Omychund v. Barker, 1 Atk. 21, 33; 26 Eng. Rep. 15, 22-23, Ch. 1744).

${ }^{98}$ Bentham, Justice and Codification Petitions, 478.

99 “Sólo a través de la codificación es posible realizar la reforma que aquí se solicita -0 cualquier otra reforma efectiva, en cualquier forma” (ibíd., 430).

${ }^{100}$ Postema, Bentham and the Common Law, 282.

${ }^{101}$ ibíd., 283.
} 
pesar de esas protestas, una teoría del derecho no puede no implicar (parte de) una teoría de la adjudicación ${ }^{102}$. La vinculación entre ambas teorías es relativamente sencilla de establecer, y se basa en la obvia observación de que, de acuerdo al derecho, los jueces tienen la obligación jurídica de aplicar el derecho. Ahora bien, una teoría del derecho es una teoría de qué es el derecho, es decir, una teoría de qué cuenta como derecho. Si el juez tiene la obligación jurídica de decidir un caso conforme a derecho, se sigue que tiene la obligación jurídica de decidir un caso conforme a lo que, de acuerdo a la teoría correcta, es derecho (la frase en cursivas por supuesto está implícita en la frase anterior: la oración "es derecho lo que de acuerdo a la teoría correcta es derecho” es tautológica). Una teoría del derecho, cualquier teoría del derecho, es, adicionalmente a cualquier otra cosa que sea o incluya, (parte de) una respuesta a la pregunta por el contenido del deber jurídico del juez de decidir conforme a derecho.

Consideremos ahora, como ejemplo, cómo una visión del derecho como la de Hart se refleja en su forma de entender el razonamiento jurídico. A mí parecer en el capítulo VII de El Concepto de Derecho ${ }^{103}$ uno puede encontrar dos versiones de la tesis de la "textura abierta", una que la entiende como una tesis sobre el lenguaje y no como una tesis sobre el derecho (textura abierta=vaguedad, que es el reflejo de una característica de las palabras y conceptos de los lenguajes naturales y se comunica al derecho sólo porque éste se expresa en esos términos) y una en la que ella es una tesis sobre el derecho (textura abierta=inadecuación, que es el reflejo de nuestra relativa indeterminación de fines e ignorancia de hecho) ${ }^{104}$. En el primer caso, Hart

${ }^{102}$ Las líneas que siguen contienen sólo un esquemático resumen de un argumento más complejo, formulado en Atria, Law and Legal Reasoning, 168-171 (véase Atria, "Del derecho y del razonamiento jurídico”, 88-90).

${ }^{103}$ Hart, Concept of Law, 126-131 [157-163].

${ }^{104}$ Para expandir un poco la explicación contenida en los paréntesis, de acuerdo a la primera interpretación, la tesis de Hart era una tesis sobre el lenguaje en que las reglas se expresaban, y por eso sólo mediatamente sobre las reglas mismas. Como los conceptos de los lenguajes naturales son open textured, las reglas expresadas en ellos también lo son. Así, por ejemplo: “cualquiera sea la técnica, precedente o legislación, que se escoja para comunicar pautas o criterios de conducta, y por mucho que éstos operen sin dificultades respecto de la gran masa de casos, en algún punto en que su aplicación se cuestiones las pautas resultarán indeterminadas” (ibíd., 127s [159]); de acuerdo a la segunda interpretación la tesis no es sobre el lenguaje en que las reglas jurídicas se expresan, sino sobre lo que es razonable pretender dada la condición humana. Aquí el argumento es inmediatamente sobre las reglas jurídicas y lo que es razonable esperar de ellas o pretender con ellas. Si no fuera porque tenemos "relativa ignorancia de los hechos” y "relativa indeterminación de propósitos", "podríamos elaborar reglas cuya aplicación a los casos particulares nunca exigiera una nueva elección” (Hart, Concept of Law, 128 [160]). La cuestión es detalladamente discutida en Atria, Law and Legal Reasoning, 161-167 (Atria, “Del derecho y del razonamiento jurídico”, 80-83). 
se transforma en formalista porque la forma en su respuesta a la pregunta que abre su libro (¿Qué es el derecho?) contribuye a dar contenido al deber jurídico del juez de decidir conforme a derecho implica que el derecho no puede ser, en términos de Bentham, "acomodaticio"; en el segundo, se vuelve escéptico, porque la solución jurídicamente correcta de un caso no se sigue de las reglas válidas sino de la forma en que, dadas esas reglas, ha de resolverse la competencia entre las necesidades sociales de certeza y adecuación. Como estas necesidades sociales son obviamente valores morales (una etiqueta que sin embargo Hart cuidadosamente evitón ${ }^{105}$ ), la solución correcta de un caso, de cada caso, dependerá del juicio moral del juez. En términos hartianos, esto es escepticismo ante las reglas, porque significa que las reglas siempre requieren una nueva decisión ("fresh judgment”), caso a caso, para poder ser aplicadas ${ }^{106}$. Podemos ver cómo el ciclo de la adjudicación de Bentham se presenta: absolutistas desilusionados se vuelven escépticos antes las reglas ${ }^{107}$, sólo para transformarse en escépticos desilusionados (espantados por la arbitrariedad de la primera etapa), volviéndose entonces formalistas, y así sucesivamente. La razón de esto no se encuentra en alguna peculiaridad de la teoría del derecho de Hart ${ }^{108}$. En el capítulo VII de El Concepto de Derecho encontramos que Hart sin quererlo se anticipó al problema al que se enfrentan los positivistas duros y suaves: el correlato teórico del ciclo de la adjudicación, constantemente oscilando entre formalismo y escepticismo mientras la práctica oscila entre rigidez y arbitrariedad.

¿Es el ciclo de la adjudicación un acertijo que puede ser resuelto, o es parte indefectible de la condición humana? Para responder esta pregunta debemos regresar a la idea de Postema de que el ciclo se manifiesta porque los jueces deben tanto asegurar la certeza y la predecibilidad como la adecuación de la solución dada al caso en cuestión. Bentham (Postema) creía que el acertijo se resolvía con la introducción de un nuevo criterio de validez (i.e. derecho legislado, válido porque era puesto), de manera que las decisiones

105 Tanto en The Concept of Law como en Hart, "Positivism and the separation”, 66-69 [51-56], donde se refiere a "metas sociales" o "fines", "las nuevas necesidades de la sociedad" y términos semejantes.

${ }^{106}$ Un escéptico ante las reglas niega “que la vida del derecho consista en una gran medida en la orientación tanto de los funcionarios como de los individuos privados por reglas determinadas que, a diferencia de la aplicación de estándares variables, no requieren de una nueva valoración [fresh judgment] en cada caso" (Hart, Concept of Law, 135 [168s]; el énfasis es de Hart).

107 ibíd., 138-9 [173].

${ }^{108}$ He intentado explicar cómo la misma tensión se encuentra en la obra de Raz, Schauer y MacComirck en Atria, "Del derecho y del razonamiento jurídico”, 97-117; véase también Atria, Law and Legal Reasoning, 177-195. 
judiciales no fueran la única fuente de reglas jurídicas. Sin embargo, la historia del positivismo jurídico continental probó que esto era un error, porque la versión europea del positivismo jurídico hizo al juez ciego a las particularidades del caso concreto tal como el common law lo hizo con los jueces ingleses según Bentham, tal como también lo haría el positivismo normativo excluyente de Waldron. La solución al ciclo se encontrará en una versión del positivismo ético que permita una forma de argumentación jurídica abierta a consideraciones morales (al por menor) de modo que permita identificar los casos recalcitrantes, una que permita al juez ver y hacerse cargo en sus propios términos del caso particular al que se enfrenta, pero que no implique por eso la disolución del razonamiento jurídico en razonamiento moral.

Acometer una tarea de este tipo exige una teoría de la distinción entre legislación y jurisdicción. En estos días post-Montesquieu, sin embargo, carecemos de esa teoría como esa, y ésta no es la oportunidad para comenzar a formularla ${ }^{109}$. Lo importante ahora es que entendamos lo que está en juego, por qué un nuevo positivismo benthamita es urgente. La razón es que a pesar de que la crítica de Bentham al common law fue lo suficientemente efectiva como para convertirse en la nueva ortodoxia, hoy somos testigos de una suerte de involución jurídica a formas pre-modernas de derecho, que debe ser resistida. El positivismo ético es una teoría que explica por qué y cómo esta involución debe ser resistida. La ironía está en que el positivismo jurídico contemporáneo no sólo mira a este problema con indiferencia (o mejor: reclama insistentemente que no lo mira en absoluto), sino que se ha convertido, como hemos visto y volveremos a ver, en un estrecho aliado de los equivalentes contemporáneos de “Judge \& Co.” y sus “siniestros intereses".

\section{Neo-constitutionalismo como derecho pre-moderno}

Un nuevo fantasma recorre Europa -el fantasma del neo-constitucionalismo. Los poderes de la cultura jurídica europea han entrado en una santa alianza no para exorcizarlo sino para defenderlo e incluso exportarlo: jueces y abogados, académicos y profesores de derecho, intelectuales italianos y filósofos alemanes.

El primer fantasma prometía emancipación pero finalmente llevó al totalitarismo; el segundo promete libertad e igualdad para todos pero pone en peligro nuestra capacidad para autogobernarnos democráticamente y el Estado de Derecho como gobierno de las leyes, y no de hombres y mujeres.

${ }^{109}$ Véase Atria, “Jurisdicción e independencia judicial”. 
El neo-constitucionalismo es una "corriente de pensamiento" 110 que enfatiza el surgimiento, a partir de la segunda mitad del siglo XX, de una diferente comprensión de la dignidad de la legislación y su relación con la constitución; diferente, en particular, de la comprensión del positivismo europeo del siglo XIX. Mientras este última era legalista en el sentido de defender la supremacía del legislador, el neo-constitucionalismo defiende la supremacía de la constitución. Como consecuencia, "la legislación, por primera vez en los tiempos modernos, está subordinada a un nivel legal superior establecido por la constitución" ${ }^{111}$. Pero eso no es todo. El derecho neo-constitucionalista incluye normas constitucionales redactadas en términos amplios que hacen referencia a principios morales y enfatiza que esos principios constitucionales son normas aplicables como las leyes ordinarias, que han de ser interpretadas a través de un proceso de ponderación y balance en vez de la subsunción de casos individuales en casos genéricos solucionados por normas generales ${ }^{112}$. Esto lleva a una concepción del derecho guiada por un "pluralismo de principios"113 y a una ciencia del derecho "líquida" o "flexible"114. El resultado es que los jueces (y la ciencia del derecho) ya no son sirvientes de la ley, sino que tienen un deber más fundamental con la constitución. En cumplimiento de ese deber fundamental el juez debe erigirse en juez del legislador.

El paso del modelo legalista tradicional al neo-constitucionalismo es una instancia del ciclo de la adjudicación de Bentham: el énfasis, característico del neo-constitucionalismo, en una forma deformalizada, pluralista, líquida o flexible de interpretación y adjudicación puede ser entendido como una reacción al positivismo europeo del siglo XIX ${ }^{115}$. Pero el neo-constitucionalismo arroja al bebé junto con el agua de la bañera. Su énfasis en el rol jurídico de los principios constitucionales, y su indiferencia hacia el valor y dignidad de la legislación, pone en riesgo la idea de autogobierno democrático (que constituye al menos el ideal regulativo que funda nuestras prácticas

${ }^{110}$ Pozzolo, “Neoconstitucionalismo”, 339. La caracterización general del neo-constitucionalismo ofrecida en este párrafo sigue la de Pozzolo en este artículo, pp. 340-342.

${ }^{111}$ Zagrebelsky, Derecho Dúctil, 34.

112 Aquí estoy utilizando terminología tomada de Alchourrón and Bulygin, Normative Systems, 27-34 [57-65].

${ }^{113}$ Zagrebelsky, Derecho Dúctil, 122-126.

114 ibíd., 17-18.

${ }^{115}$ Por supuesto, no es este el único factor. Uno de los más habitualmente invocados (vid. e.g. Beatty, The Ultimate Rule of Law, 2-5) es la finalidad de "evitar que las atrocidades que se han cometido en el nombre del pueblo ocurran de nuevo” (ibíd., 2). La idea de que a través de tribunales es posible prevenir el genocidio y el exterminio es al menos discutible. Véase Atria, "La hora del derecho". 
democráticas, de acuerdo al cual somos nosotros, el pueblo quienes nos autogobernamos) y la idea de gobierno conforme a derecho. La razón por la que el neo-constitucionalismo tiene este peligroso potencial es, sorprendentemente, la misma razón que algunos neo-constitucionalistas invocan como su fundamento: el creciente pluralismo de las sociedades contemporáneas. Nuestro compromiso constitutivo, “constitucional”, con valores como los que usualmente se contienen en las declaraciones constitucionales, no sólo es limitado por, sino estrictamente supone, profundos desacuerdos sobre la forma en que esos valores deben ser entendidos ${ }^{116}$. El hecho del pluralismo, pace autores como Zagrebelsky ${ }^{117}$, hace más y no menos importante la preservación de la esfera de autonomía (sin duda relativa) del razonamiento jurídico ${ }^{118}$.

Aunque sus defensores no parecen estar concientes de ello, el neo-constitucionalismo es derecho premoderno. En efecto, las similitudes entre ambos "paradigmas" no pueden pasar inadvertidas. L. Ferrajoli, por ejemplo, ha sostenido que es posible distinguir tres "paradigmas" de derecho, que identifica con "el derecho premoderno, el Estado legislativo de derecho y el Estado constitucional de derecho" ${ }^{119}$. De acuerdo a Ferrajoli estos "paradigmas" se diferencian entre sí por las diversas concepciones que cada uno de ellos tiene de “a) la naturaleza y estructura del derecho, b) la naturaleza de la ciencia jurídica, y c) de la jurisdicción”. En cuanto a lo primero, el paradigma pre-moderno entendía (como hemos visto más arriba, aunque con otro lenguaje) que la validez del derecho dependía del "desarrollo y actualización” de las categorías tradicionales, cuya validez a su vez dependía "no ya de la forma de su producción, sino de la intrínseca racionalidad o justicia de sus contenidos”. El Estado legislativo reemplaza esta fuente de autoridad del derecho por la autoridad del Estado. En la fórmula de Hobbes, que Ferrajoli cita, tratándose del derecho moderno auctoritas, non veritas facit legem ${ }^{120}$. En cuanto a lo segundo, mientras la ciencia jurídica premoderna se encargaba de reelaborar la sabiduría de la tradición recibida por los doctores y era por consiguiente "inmediatamente normativa, y se

${ }^{116}$ Mouffe, El Retorno de lo Político, 18-19. Véase también Atria, “La hora del derecho”.

117 Zagrebelsky, Derecho Dúctil, 125: “es fácil entender que un derecho de principios es más propicio [que un derecho de reglas] a la sobrevivencia de una sociedad pluralista”.

${ }^{118}$ Que se manifiesta en el hecho de que "la manera en que cada uno de nosotros identifica una decisión como "nuestra" debe [...] parecer arbitraria en relación a [nuestras opiniones sobre qué es correcto hacer” (Waldron, Law and Disagreement, 105s). Para una defensa filosófica de una forma de positivismo que rescata la importancia de esta autonomía, véase adicionalmente Campbell, Ethical Positivism.

${ }^{119}$ Ferrajoli, "Pasado y futuro del Estado de derecho”, 14.

${ }^{120}$ ibíd., 15. 
identificaba de hecho con el derecho mismo”, la ciencia jurídica moderna pasa a entenderse como no normativa sino cognoscitiva, en tanto pretende explicar y reconstruir un objeto “autónomo y separado de ella”, los dogmas legales. La caracterización de la función jurisdiccional, por último, también cambia radicalmente. La función del juez ya no era dar al caso sometido a su conocimiento la solución justa de acuerdo a la sabiduría recibida, sino declarar cuáles eran para ese caso las consecuencias contenidas de antemano en la norma legislada. Eso explica "el carácter tendencialmente cognoscitivo de la jurisdicción [moderna]”.

Ferrajoli muestra que el modelo del Estado legislativo está siendo reemplazado por un modelo alternativo, un tercer modelo a su juicio, el del Estado constitucional. Ahora la validez de las leyes depende “ya no sólo de la forma de su producción sino también de la coherencia de sus contenidos con los principios constitucionales”; la ciencia jurídica adquiere un papel “crítico y proyectivo en relación con su propio objeto", al punto que es ahora capaz de imponer "prohibiciones y obligaciones de contenido" al legislador. La función jurisdiccional es también reconceptualizada, porque ahora ésta debe “aplicar la ley sólo si es constitucionalmente válida, y cuya interpretación y aplicación son siempre, por esto, también un juicio sobre la ley misma que el juez tiene el deber de censurar como inválida mediante la denuncia de su inconstitucionalidad cuando no sea posible interpretarla en sentido constitucional" ${ }^{121}$.

En suma, el derecho neo-constitucionalista es un derecho que vale porque corresponde a criterios de justicia que no fluyen sino pueden oponerse al derecho positivo; la ciencia jurídica es normativa en tanto impone deberes y obligaciones al legislador (y, por qué no añadir, al juez), y la función judicial es resolver conforme a la ley sólo si la ley no merece al juez un reproche de constitucionalidad. veritas, non auctoritas facit legem! El derecho del Estado constitucional de Ferrajoli no es un tercer paradigma de derecho: es el mismo viejo paradigma pre-moderno.

Por supuesto, un defensor del neo-constitucionalismo que se sintiera incómodo con esta conclusión podría atacar su primera premisa: los criterios de valor no surgen con autonomía del derecho positivo, sino de un texto puesto, la constitución. Pero la constitución para el neo-constitucionalista no es un texto positivo, es lo que ese texto positivo significa, como lo ha sostenido explícitamente Ronald Dworkin, en su mejor "lectura moral”122. El abogado neo-constitucionalista carece de la preocupación del jurista moder-

\footnotetext{
${ }^{121}$ ibíd., 18.

${ }^{122}$ Para la idea de una “lectura moral” de la constitución, véase Dworkin, Freedom’s Law,
} $1-38$. 
no por los textos legales. Para citar un caso conocido, la enmienda catorce de la constitución norteamericana contiene una cláusula de igual protección que está redactada como si fuera una cláusula que impone obligaciones sólo a los gobiernos estatales ("no state shall deny...”). Desde el punto de vista de la justicia, por supuesto, la desigual protección no es menos oprobiosa porque la realice una órgano federal. Por eso cuando la Corte Suprema debió decidir, después de decidir Brown v. Board of Education ${ }^{123}$, sobre la constitucionalidad de la segregación en las escuelas del Distrito de Columbia (que no es un estado), el hecho de que conforme a su letra la enmienda catorce no era aplicable al distrito de Columbia no fue un argumento de peso ${ }^{124}$.

De lo anterior no puede extraerse la conclusión de que Bolling v. Sharpe estuvo mal decidido. Lo que si puede concluirse es que el caso estuvo bien decidido a pesar de que fue decidido en contra de la letra de la enmienda catorce, y eso muestra algo acerca de cómo (no) pesa la letra cuando de interpretación constitucional se trata.

Un caso que prueba algo similar, pero que es más controvertible, es el que enfrentaron los tribunales alemanes después de la reunificación cuando se trató de condenar a los guardias del muro de Berlín que abatieron a personas que intentaban cruzar la frontera de la República Democrática sin autorización. La pregunta constitucional aquí era si al condenarlos se infringía el art. 103.2 de la Ley Fundamental alemana, que prohíbe la retroactividad de la ley penal. Comentando aprobatoriamente la decisión del Tribunal Constitucional Federal, Robert Alexy observa que el tribunal decidió que la prohibición de retroactividad del art. 103.2, a pesar de estar redactada en términos absolutos, está sujeta a ponderación, de modo que "es elástico sin dejar de ser una norma dura”125. Esto parece estar, dice Alexy, expuesto a la objeción de que "vulnera el tenor literal de la constitución, toda vez que el art. 103.2 LF no contiene cláusula de excepción alguna” ${ }^{126}$. Pero esta no es una objeción poderosa frente a un neo-constitucionalista. Alexy dice que "esta objeción ha de tomarse muy en serio”"127, porque después de todo la adjudicación constitucional se presenta como adjudicación y no como justicia del Cadí. La manera en que responde esta objeción muestra, sin embargo, que no se la toma en serio. Alexy cree que es justificación suficiente para permitir la ponderación, tratándose de un artículo que consagra lo que es probablemen-

\footnotetext{
${ }^{123}$ Que, como se sabe, objetaba la constitucionalidad de la doctrina "separados pero iguales” adoptada por el estado de Kansas 347 US 483 (1954).

${ }^{124}$ Bolling v. Sharpe, 347 US 497 (1954).

${ }^{125}$ Alexy, "Derecho injusto”, 216.

126 ibíd.

127 ibíd., 217.
} 
te una de las garantías más evidentes y fuertes del derecho penal moderno, la referencia a la "justicia material” como "valor jurídico dotado de rango constitucional”, en tanto “anejo al principio del Estado de Derecho" ${ }^{128}$. En otras palabras, lo que vale en la constitución es el valor de justicia que se le imputa; ella no es contingente, su contenido no depende de lo que haya decidido un legislador constitucional. Si las palabras utilizadas indican que no hay ponderación aceptable y la justicia reclama la ponderación, entonces la constitución, correctamente entendida, exige ponderación. Por eso no es raro que un neo-constitucionalista pueda decir que "a diferencia del concepto de derecho, la justicia es un ideal local, no universal” ${ }^{129}$. En realidad, puede decirse que aquí estoy deteniéndome en lo obvio, porque no creo que ningún neo-constitucionalista auto-conciente dispute esto. Entonces tampoco podrá objetar nuestra primera premisa: la constitución no es un texto positivo, el texto positivo que llamamos constitución es un conjunto de proposiciones normativas que describen (con mayor o menor éxito) la constitución.

La ironía es que, como los grupos anti-romanos de Monty Python's Life of Brian, el positivismo actual es el mejor partidario posible de la lectura moral de la constitución. Si al incorporar conceptos moralmente cargados las constituciones se han puesto a sí mismas (y a los criterios de validez de las leyes, al menos -por el momento- los negativos) más allá de los límites del derecho, entonces sólo cabe preguntarse cuál es la mejor manera de decir estas cuestiones en sus propios términos, es decir, en términos puramente morales $^{130}$. Esto no es, como cree Dworkin, sólo una razón a favor de la lectura moral (si la constitución ha de ser aplicada como cualquier otra ley la lectura moral es ineludible), sino en contra de entender a la constitución como derecho en el mismo sentido en que una ley es derecho. Si como sostuvo Ihering, "el derecho no tolera la ausencia de forma" ${ }^{131}$, entonces el neo-constitucionalismo es incompatible con el derecho como forma de argumentación y regulación. El neo-constitucionalismo es la disolución del derecho.

Por supuesto, el positivista, duro o suave, reclamará que no está preocupado del valor de la legalidad sino de la cuestión "conceptual” de lo que es el derecho, y el “concepto” de derecho debería cubrir tanto al derecho

${ }^{128}$ ibíd

129 Beatty, The Ultimate Rule of Law, 167.

${ }^{130}$ Por esto Kelsen se oponía a la introducción de esas normas al derecho judicialmente aplicable: "Si se desea restringir el poder de los tribunales, y con ello el carácter político de su función [...], las normas constitucionales a disposición de un tribunal constitucional para su aplicación [...] no deben emplear terminología difusa, como 'libertad', 'igualdad', 'justicia', etc” (Kelsen, ¿Quien debe ser el Defensor de la Constitución?, 33).

${ }^{131}$ Ihering, Espíritu del Derecho Romano, 645 (L2 §50). 
"legalista” como al "neo-constitucionalista”. Sólo una vez que hemos aclarado la cuestión conceptual de qué es el derecho, diría, es posible abordar la cuestión política de si el argumento contra el neo-constitucionalismo es o no exitoso.

El problema es que las cuestiones conceptuales y substantivas no están aisladas una de otra: como veremos en el siguiente apartado, la reconstrucción teórica de una práctica no es como la descripción de los movimientos de los cuerpos celestes (sostener lo contrario a estas alturas es un caso de falsa conciencia). La posición conceptual del positivista analítico de hecho no se mantiene agnóstica respecto de las cuestiones políticas sustantivas, al menos en lo que se refiere a la política de la adjudicación. En efecto, sabemos que el positivista analítico debe concluir que cuando el derecho incorpora reglas como las contenidas en lo que se denomina "parte dogmática” de los textos constituciones (derechos fundamentales etc) habremos dejado la esfera de las normas basadas en fuentes y habremos entrado en consecuencia en la esfera de la discreción judicial. Hemos visto que algunos positivistas creen que pueden limitar o dirigir esa discreción, pero en realidad no pueden: por definición (i.e. porque se refiere a la aplicación de consideraciones morales acerca de la mejor interpretación de esas disposiciones constitucionales 0 , como dicen los que hacen explícito su escepticismo, las preferencias de quien decide) ellas no pueden ser jurídicamente controladas si el positivismo jurídico contemporáneo es correcto como una teoría del derecho porque (nuevamente: por definición) cualquier teoría que sostenga que el derecho es reducible a (alguna clase especial de) convención debe necesariamente concluir que cuando la convención es incierta o inexistente no hay convención, y por consiguiente hemos encontrado los "límites del derecho"132. El positivista no tiene aquí argumentos contra el neo-constitucionalista, porque el positivista ha aceptado de antemano que por la introducción de estas disposiciones constitucionales el juez encargado de su aplicación tiene discreción. Si tiene discreción, esto significa que la elección entre la lectura moral del neo-constitucionalista y cualquier otra lectura que alcance un mínimo de plausibilidad argumentativa es jurídicamente indiferente.

Sin embargo, el neo-constitucionalista dice mucho más, aunque en este punto el positivista ha perdido todo interés. El neo-constitucionalista trata de convencer a los jueces y a la profesión jurídica que su respeto por las decisiones legislativas está fuera de lugar, que ellos deben reemplazarlo por un respeto incondicional a la constitución. Y contra esto, los reclamos de los positivistas suenan vacíos. Como J.J. Moreso ha señalado en su respuesta a

${ }^{132}$ Véase la discusión sobre la importancia de la idea de los "límites del derecho” en Navarro, “Casos difíciles” y Atria, “Entre jueces y activistas”, 162-165. 
P. Comanducci ${ }^{133}$, es extraño que quien adhiere a una tesis escéptica sobre la interpretación (como todo positivista, al menos cuando se trata de conceptos jurídicos que deben parte de su contenido a la moral) objete la incertidumbre jurídica derivada de la concepción neo-constitucionalista. La crítica no es contra la incoherencia de la objeción, porque el positivista analítico puede ser (como Comanducci) analíticamente fino. La crítica es que el positivista ha removido el suelo sobre el cual podría erguirse para formular su crítica, porque su alternativa a la incertidumbre del neo-constitucionalismo no es la certeza del derecho, sino la incertidumbre de la discreción o arbitrariedad judicial cuando el juez se enfrenta a reglas como las contenidas en la mayoría de las constituciones. Y cuando el péndulo de Bentham haya oscilado de vuelta desde la rigidez del formalismo del siglo XIX a una práctica jurídica y a un ethos judicial neo-constitucionalista terminaremos con una forma de derecho pre-moderno según la cual las decisiones legislativas son sólo proposiciones normativas, que informan al juez de cuál es en principio la correcta solución del caso, y que por consiguiente siempre pueden ser, como las reglas del derecho romano (véase D. 50.17.1.pr), incorrectas descripciones del derecho (cuando el juez crea que infringen o no respetan derechos constitucionales, fundamentales, humanos, etc), siempre sujetas a la última palabra de éste, no sólo como una cuestión de hecho (puesto que sus decisiones son siempre finales: definitividad en términos hartianos) sino como una cuestión de derecho, en el sentido que la función judicial ya no está subordinada a la legislación pero sí a su propia "lectura moral" de la constitución (infalibilidad en esos mismos términos).

Contra esta perspectiva pesimista, la experiencia de los países europeos durante los últimos 50 años podría ser invocada como un contraejemplo. El neo-constitucionalista, después de todo, está tratando de hacer explícito lo que ve en la "realidad de la vida concreta del orden legal"134. 50 años de neo-constitucionalismo no ha resultado en un sistema que es arbitrario hasta la perfección como Bentham lo creía. Pero la mayoría de edad del así llamado Estado "constitucional" (como opuesto al Estado "legislativo" del siglo XIX) es bastante reciente ${ }^{135}$; aún queda por ver cuáles serán sus efectos en la auto-imagen de la profesión jurídica y a través de ella en las distintas culturas legales. Ya hemos visto que muchas de las características del dere-

\footnotetext{
${ }^{133}$ Moreso, "Comanducci sobre neoconstitucionalismo”, 273. Moreso se refiere a la crítica de Comanducci del neo-constitucionalismo en Comanducci, "Formas de neoconstitucionalismo”.

134 Zagrebelsky, Derecho Dúctil, 145.

${ }^{135}$ Para el sentido de la expresión "mayoría de edad” de una visión del derecho, véase supra, n. 50.
} 
cho moderno habían hecho su aparición en la realidad de la vida concreta del orden legal antes de 1776 y 1789. Pero para que esa idea constituyera la forma normal, obvia de auto-comprensión de la práctica jurídica fue necesario esperar (al menos) varias décadas después de la revolución.

La pregunta, entonces, no es qué es lo que los neo-constitucionalistas disciernen en la vida concreta de los ordenes legales, sino cómo es razonable pensar que una práctica auto-concientemente neo-constitucional será en condiciones de fragmentación del discurso moral. Quizás hasta ahora las consecuencias no han sido dramáticas porque (o cuando) las prácticas jurídicas que los neo-constitucionalistas comentan todavía son, al nivel de la auto-comprensión intuitiva de los participantes, prácticas que responden al modelo positivista-legalista del siglo XIX. Pero ¿es sostenible ese ethos positivista en una práctica auto-concientemente neo-constitucionalista? Quizás la respuesta deba tomar en cuenta la sociología de esas prácticas. Es sensato pensar que ciertas culturas jurídicas estarán mejor preparadas que otras para resistir las tendencias de-formalizadoras del neo-constitucionalismo. Mi impresión es que, en los sistemas continentales, esto tiene que ver con la capacidad de la ciencia jurídica de reconstruir de manera racional los materiales jurídicos disponibles: en países en los que la tradición de la ciencia jurídica (o cualquier función equivalente) es débil, el neo-constitucionalismo significa arbitrariedad hasta la perfección. Pero esta reconstrucción racional sólo puede proceder si asumimos que hay algo que puede ser racionalmente reconstruido, que algunas construcciones son jurídicamente correctas mientras que otras son jurídicamente erróneas, y esto es lo que el positivismo jurídico contemporáneo hace imposible ${ }^{136}$.

${ }^{136}$ El tipo de reconstrucción racional que tengo en mente es ejemplificado por Alonso, "Un caso difícil”. Aplicando el modelo de análisis desarrollado en Alchourrón and Bulygin, Normative Systems, Alonso encuentra una laguna normativa en las reglas del Código Civil español sobre prestaciones mutuas como consecuencia del ejercicio exitoso de una acción reivindicatoria. El poseedor vencido tiene derecho a que se le abonen las mejoras realizadas a la cosa, dependiendo de dos criterios: su buena o mala fe, y el tipo de mejoras que ha realizado (necesarias, útiles y voluptuarias o superfluas). De acuerdo a Alonso, el caso del poseedor de mala fe que ha realizado mejoras útiles no está solucionado por las reglas de ese Código. A pesar de eso Alonso reconstruye la racionalidad de las reglas involucradas y formula dos principios: que el poseedor de buena fe está mejor o igual que el de mala fe, y que el poseedor que ha realizado expensas necesarias está en mejor o igual posición que el que ha realizado expensas útiles, que a su vez está mejor o igual que el que ha realizado expensas voluptuarias (nótese la modestia substantiva de los principios, reconocible por cualquier abogado). Aplicando estos principios la laguna que Alonso había encontrado tratándose del poseedor de mala fe que ha realizado expensas útiles es solucionada (en realidad Alonso no llega tan lejos. Él cree que aun aplicando estos principios hay dos soluciones que mantienen la coherencia del sistema, pero si la reconstrucción nos ha permitido avanzar algunos pasos, ya no hay razón a priori para negarse a la posibilidad de que iterando el argumento, ampliando el ámbito de las reglas en consideración (etc) sea posible llegar a concluir que una de esas dos soluciones es la correcta). Sin embargo, 
El derecho neo-constitucionalista es derecho pre-moderno, “semi-bárbaro" en el sentido de Bentham ${ }^{137}$. El mismo Zagrebelsky se da cuenta que dejar atrás el Estado legislativo puede acarrear el riesgo "de volver a la situación pre-moderna de inseguridad e imposición forzada”" ${ }^{338}$. Él cree que el riesgo puede evitarse. Y aquí llegamos a un punto que quizás debería haber sido explicitado antes: ¿por qué es un problema que el neo-constitucionalismo sea pre-moderno? ¿Hay algo intrínsecamente objetable en una visión pre-moderna del derecho? La respuesta a esta segunda pregunta puede ser por ahora negativa. El derecho pre-moderno puede no haber sido especialmente inconveniente o arbitrario para tiempos pre-modernos. Pero la pregunta es si hay alguna razón por la que un derecho pre-moderno sea

recuerdo la reacción que tuvo un grupo de profesores auto-caracterizados como positivistas cuando Alonso presentó su investigación en una reunión en Bahía Blanca, Argentina: ellos (amablemente, desde luego) argumentaron que la de Alonso era simplemente una de las múltiples reconstrucciones lógicamente posibles, y como tal no tenía ningún valor especial (y, claro, sobre dos puntos pasan infinitas curvas). Desde el punto de vista de las reglas aplicables, ellos creían que no había ninguna razón para decir que el juez tenía un deber más intenso de buscar la solución correcta, habiendo verificado previamente que se trataba de una laguna normativa, que de fallar reconociendo al poseedor de mala fe que había realizado expensas útiles una posición mejor que la del poseedor de buena fe que había realizado expensas necesarias, o que la del de mala fe que había realizado expensas voluptuarias. Que las reconstrucciones a las que me refiero son imposibles en el contexto de una teoría de las hoy llamadas "positivistas" del derecho puede ser mostrado de otra forma. En alguna oportunidad discutíamos con Jorge Rodríguez el problema de la derrotabilidad de las normas jurídicas, utilizando entre otras cosas el ejemplo propuesto por Lon L. Fuller. En este caso, se trataba de una regla que sancionaba con multa a quienes duerman en la estación, que debía ser aplicada a dos casos: el de un "hombre de negocios” que se duerme momentáneamente mientras espera su tren atrasado a las 3:00 AM, y el de una persona sin casa que se instalaba con sus escasas pertenencias en un banco de la estación a pasar la noche pero que es arrestado antes de alcanzar a dormirse (véase Fuller, "Positivism and fidelity to Law”, 664). Rodríguez creía que la noción de derrotabilidad no era suficiente para solucionar los problemas de aplicación de esta norma, porque le parecía imposible "justificar racionalmente la imposición de una pena (¡de multa!) a una persona por carecer de vivienda” (Rodríguez, “Imagen actual”, 156). Nada nuevo todavía, porque yo imagino que para un positivista como Rodríguez que una ley carezca de justificación racional no dice nada en contra de su calificación de norma jurídica. Pero Rodríguez continua: la constitución argentina contiene una regla que prohíbe la imposición de sanciones por conductas que "de ningún modo ofendan al orden y a la moral pública ni perjudiquen a un tercero” (ibíd.). Según Rodríguez, esta regla muestra de modo categórico (en el sentido de que cualquier otra conclusión le "parece inadmisible": ibíd.) que la norma de Fuller "sería inconstitucional de conformidad con el derecho argentino”. Habría entonces que concluir que el juez no está obligado por la regla de Fuller (y por cualquier otra regla que sea a su juicio inconstitucional), pero como la inconstitucionalidad de las reglas legales depende de interpretaciones discutibles de conceptos moralmente cargados, para decir cuáles reglas obligan al juez éste tendría discreción. Es difícil evitar el escepticismo radical llegado a este punto (la cuestión es discutida con más detalle en Atria, "Entre jueces y activistas”, 164. Véase adicionalmente Moreso, “A Brilliant Disguise”, 200)

${ }^{137}$ Véase el epígrafe de esta sección.

${ }^{138}$ Zagrebelsky, Derecho Dúctil, 12. 
objetable en nuestras condiciones modernas o post-modernas. ¿Qué puede decirse contra el derecho pre-moderno? La respuesta es: si creemos que nuestro mundo es cuidado y mantenido por la divina providencia, que nuestra sociedad está naturalmente ordenada, y que entre nosotros no existe desacuerdo político que no sea solucionable a través de la argumentación y por referencia a formas aceptadas y dominantes de razonamiento y autoridad moral, de modo que podemos aceptar la pretensión de una elite profesional de jueces y abogados de tener una vía de acceso epistemológicamente privilegiada a la sabiduría práctica que se requiere para decidir los asuntos más fundamentales que nos afectan, nada ${ }^{139}$.

\section{Positivismo ético, teórico, metodológico}

¿Cómo es que hemos llegado a esta situación? ¿Cómo es que una teoría que surge para afirmar la artificialidad y autonomía del derecho ha terminado fomentando la deformalización del derecho, la vuelta a una forma de derecho pre-moderna, que es precisamente la forma de derecho que la teoría pretendía originalmente combatir? Creo que la respuesta está relacionada con la forma de entender el problema de la teoría del derecho, con qué es aquello que quien se dedica a la teoría del derecho intenta hacer. Una manera de explicar esta idea es considerar la famosa distinción de Norberto Bobbio entre positivismo metodológico, teórico e ideológico. Esta distinción, por supuesto, ha sido uno de los aspectos del pensamiento de Bobbio más influyentes. En el mundo hispano-parlante en general quienes hemos aprendido sobre el positivismo jurídico en los últimos treinta años lo hemos hecho, en parte al menos, a través de ella.

Nuestra pregunta original podría ser formulada de la siguiente manera: ¿cómo es que las tres formas de positivismo fueron separadas? Si la reconstrucción que he hecho del positivismo de Bentham es correcta, es posible entender que esos tres "sentidos” de la idea de positivismo jurídico no podían ser concebidos como si fueran independientes unos de otros: el objetivo (“ideológico”) de afirmar la artificialidad y por consiguiente la autonomía del derecho moderno implica una teoría del derecho conforme a la cual su forma paradigmática de manifestación de derecho era la ley, porque sólo la ley puede ser entendida como la "manifestación de la voluntad soberana” (art. 1 C.C. chileno), y en todo caso si ahora la autoridad del derecho era reconducible a la voluntad soberana era evidente que el derecho debía ser entendido en clave estatalista (esto es lo que Bobbio llama "po-

${ }^{139}$ Véase, si referencias fueran necesarias para justificar la proposición evidente de que éste no es nuestro mundo, MacIntyre, After Virtue, 8-22 [19-39]; Rawls, Political Liberalism, 54-66 [72-81]. 
sitivismo teórico"). Hemos visto que esa forma de positivismo era posible sólo desterrando al olvido la comprensión pre-moderna conforme a la cual el derecho era el desarrollo de la razón en la historia de acuerdo al modo que tradicionalmente ella había sido entendida, y por consiguiente el positivismo de Bentham suponía que el derecho carecía de conexión intrínseca con la razón. Si había conexión entre el derecho y la razón (moral) ella era contingente y extrínseca: estaba dada porque el soberano había actuado razonablemente (justamente) al dictar la nueva ley. Por consiguiente el jurista debía distinguir entre su rol de tal, que era puramente expositivo, y su rol de ciudadano o político, que era crítico. Las conclusiones que en esta segunda calidad alcanzara iban a ser irrelevantes para sus conclusiones en su otra calidad.

Pero, sabemos, el búho de Minerva vuela al atardecer. El positivismo alcanzó su formulación definitiva cuando la lucha por el derecho moderno ya había sido librada y ganada. Muchas de las tendencias que asociamos con el neo-constitucionalismo ya eran manifiestas al comenzar la segunda mitad del siglo XX; en particular, la idea bienestarista que se asocia con el Estado socialdemócrata en Europa y, algo más tarde, el New Deal de F. D. Roosevelt en Estados Unidos suponían el abandono del rígido formalismo jurídico del siglo XIX, identificado como hemos visto con la escuela de la exégesis; la experiencia alemana durante el régimen nacionalsocialista, por otra parte, mostró la cara horrible del derecho moderno: que el derecho sea contingente (y sólo así podemos ser libres para gobernarnos, como he insistido más arriba) quiere decir que siempre puede ser de otro modo. El derecho Nazi mostró que "de otro modo" incluye "del peor modo posible". Y el positivista, que en su batalla contra el derecho pre-moderno había defendido la contingencia del derecho, se encontraba expuesto a la terrible acusación de Gustav Radbruch:

Por medio de dos principios supo el nacionalsocialismo aherrojar a sus seguidores, por una parte a los soldados y por otra parte a los juristas: 'órdenes son órdenes’ y ‘la ley es la ley’ [...] El principio ‘la ley es la ley’ no conocía [...] limitación alguna. Era la expresión del pensamiento jurídico positivista, que dominó durante muchos decenios, casi sin ser contradicho, a los juristas alemanes ${ }^{140}$.

Adicionalmente, la urgencia de defender una forma de adjudicación legalista y una ideología positivista se había acabado, porque a esas alturas la comprensión moderna del derecho era la auto-comprensión de la práctica jurídica. En este contexto, lo que Bobbio llamaría la "teoría” y la "ideología" positivista eran un lastre que ya no había ninguna necesidad de cargar.

${ }^{140}$ Radbruch, “Arbitrariedad legal y derecho supralegal”, 127. 
Aquí yace, a mi juicio, el atractivo de la topología bobbiana: ella permite un positivismo de mínimo compromiso ontológico (i.e. “teórico”) y moral (i.e. "ideológico”). Por eso no es raro que de las tres modalidades del positivismo identificadas por Bobbio haya sido el positivismo metodológico, y no el ideológico o el teórico, el más discutido y auto-concientemente aceptado. En realidad, la tipología de Bobbio es menos una taxonomía de las diversas formas de positivismo que un argumento a favor del positivismo metodológico.

La tesis, como se sabe, es que el positivismo metodológico no supone ni implica, según Bobbio, ni el positivismo ideológico (está libre, entonces, de la adhesión práctica que el positivismo ideológico exige) ni el positivismo teórico (es decir, no supone ni implica una teoría legislativa o imperativa del derecho). Lo único que el positivismo metodológico supone es un "esfuerzo por convertir el derecho en una auténtica ciencia que posea los mismos caracteres de las ciencias físico-matemáticas, naturales y sociales” ${ }^{\text {"41 }}$. Lo que caracteriza a estas ciencias es su neutralidad valorativa, es decir, "la distinción entre juicios de hecho y juicios de valor y la rigurosa exclusión de estos últimos del horizonte del científico" ${ }^{142}$. Al declarar el positivismo metodológico independiente de la teoría y la ideología del derecho, Bobbio permitió al positivista abandonar el positivismo ideológico y su crítica a Radbruch et al. y el positivismo teórico con su concepción exegética al ingeniero social del Estado del bienestar. Desde Bobbio el verdadero positivista puede entregar estas posiciones y parapetarse en la más modesta del positivismo metodológico.

El problema con el positivismo metodológico es que en sus propios términos carece de sentido. En su momento el positivista podrá haber recibido la distinción bobbiana como una liberación, en la medida en que le permitía atender a lo que le interesaba sin tener que cargar con el lastre de la teoría y la ideología. Pero el método sólo era plausible en la medida en que la teoría y la ideología continuaran siendo las formas de auto-comprensión de las prácticas jurídicas en las que trabajaba el positivista, y en la medida en que esa auto-comprensión dejaba de creer en la supremacía del derecho creado (positivismo teórico) y en la importancia del respeto a las reglas legales como expresión de autogobierno (positivismo ideológico), el regalo de Bobbio se transformó en un presente griego que hace que los todavía autodenominados positivistas “metodológicos” o "analíticos” presenten como hemos visto un espectáculo similar a los grupos anti-romanos luchando entre sí en el palacio de Poncio Pilatos.

\footnotetext{
${ }^{141}$ Bobbio, El Positivismo Jurídico, 145.

142 ibíd.
} 
La razón por la que el positivismo metodológico caracterizado à la Bobbio es insostenible en sus propios términos es precisamente la razón por la cual es incorrecto hablar de positivismo "metodológico", explicada por el propio Bobbio: para Bobbio, el positivismo metodológico era "el positivismo jurídico como aproximación a-valorativa al derecho"143, o "modo de acercarse al estudio del derecho”"144. Bobbio explícitamente rechazó etiquetar este "modo de comprensión del derecho" como "método":

Por "modo de acercarse al estudio del derecho" entiendo algo diferente de "método"; no se trata en efecto, de los instrumentos o de las técnicas empleadas en la investigación, con respecto a las cuales el positivismo jurídico no presenta una característica peculiar, sino más bien de la delimitación del objeto de la investigación, lo que revela cierta orientación hacia el estudio de algunos problemas más que de otros, y cierta actitud frente a la función misma de la investigación ${ }^{145}$.

El positivismo "metodológico", entonces, es algo más que un método: es una tesis sobre cómo ha de delimitarse el objeto de la teoría del derecho. Pero el objeto de estudio de la teoría del derecho es el derecho; la respuesta a la pregunta por la correcta delimitación del objeto de estudio de la teoría del derecho es evidente: debe estudiar el derecho. En la medida en que el positivismo "metodológico" responde que el objeto de estudio de la teoría del derecho es lo que puede ser estudiado "a-valorativamente", descansa necesariamente sobre una teoría del derecho de acuerdo a la cual el derecho es susceptible de descripción a-valorativa. Es por esto que el positivismo metodológico no puede fundarse a sí mismo, y requiere de una teoría o de una ideología. Pero a su vez lo mismo puede decirse del positivismo jurídico como teoría, y por eso podemos decir que la forma básica de positivismo es el positivismo ideológico o ético, que es la conclusión que he tratado de defender en este artículo: el positivismo que se entiende a sí mismo como una re-presentación del derecho moderno ${ }^{146}$.

143 ibíd.

${ }^{144}$ Bobbio, El Problema del Positivismo Jurídico, 41.

${ }^{145}$ ibíd., 40 (cursivas añadidas).

${ }^{146}$ Aunque debe aceptarse que la versión que he esbozado en este artículo de un positivismo ético, i.e. una teoría del derecho moderno, no calificaría como positivismo ideológico en la tripartición de Bobbio. Para Bobbio, éste se caracteriza por conferir al derecho puesto "por el solo hecho de existir, un valor positivo, prescindiendo de toda consideración acerca de su correspondencia con el derecho ideal”. La forma en que este valor es atribuido al derecho varía (Bobbio identifica dos formas que dan origen a dos versiones del positivismo ideológico), pero "de ambas posiciones se deduce la consecuencia de que las normas jurídicas deben ser obedecidas por sí mismas, en cuanto tales; con otras palabras, la obediencia a las normas jurídicas es una obligación moral” (ibíd., 46s). Yo no creo que esto sea un necesario componente de un positivismo como el de Bentham. Como hemos visto, Bentham sostuvo que el lema del ciudadano 
Esto puede parecer una conclusión sorprendente: pareciera que el biólogo no necesita de una teoría normativa para definir los organismos que estudia. Desde luego, el biólogo necesita de una teoría del mundo, por tosca que sea, que le permita distinguir ciertos aspectos de él que estudiará; pero esa teoría no necesita ser normativa, no necesita ser una teoría de cómo sería bueno que el mundo fuera, o por qué es valioso que el mundo sea como es $^{147}$. Pero lo que acabo de decir es que el positivista metodológico requiere de una teoría sobre cómo sería bueno que el derecho fuera. ¿Por qué no podemos, como Bobbio, ver al positivista metodológico simplemente como el análogo del biólogo en relación al derecho?

es “obedece puntualmente, censura libremente” (Bentham, Fragment, 230), con lo que parece abonar la tesis de Bobbio. Pero si lo valioso acerca del derecho moderno es que éste permite el autogobierno de una polis, entonces su teoría no necesita alegar que el derecho sea valioso por el solo hecho de existir, sino porque (y cuando) permite el autogobierno democrático; es agnóstico respecto de la existencia de un deber moral de obedecer al derecho, porque eso queda entregado a una teoría del valor de la pertenencia a una comunidad política. Por supuesto, no es parte del argumento de este artículo que éstas fueron las razones por las que el propio Bentham veía valor en el derecho moderno. La tesis no es una sobre cómo entender a Bentham, sino por qué parte de lo que Bentham decía es relevante para nosotros hoy (el argumento democrático en Bentham está más cerca de la idea liberal de identificar el interés público con el privado que de la preocupación con el autogobierno propia de la tradición republicana que he enfatizado en este artículo: véase Pendás, J. Bentham, 319-328. El positivista ético puede aceptar, desde luego, que el valor del autogobierno no es el único valor decente; el contenido de nuestras decisiones no es irrelevante para decidir sobre el valor que debe reconocerse a ellas como ejercicio de autogobierno. Lo que necesita afirmar es que esta última cuestión, la de si una decisión que es institucionalmente reconocida como nuestra debe ser tratada como nuestra por cada ciudadano es una pregunta política y no jurídica, es decir, es una pregunta para el ciudadano y no para el juez; el juez que se la formula está actuando como activista disfrazado de juez, no como juez (véase Atria, “Entre jueces y activistas”; Atria, “El derecho y la contingencia de lo político”). Desde el punto de vista jurídico las decisiones que institucionalmente son nuestras "cuentan como” nuestras decisiones. El legalismo del positivismo ético es una manifestación de esto. Desde el punto de vista político el derecho no tiene respuesta a la objeción que formula el que se rebela en contra de una decisión legislativa porque le parece que el contenido de esa decisión es demasiado injusta como para aceptarla como una decisión en parte de él. El derecho lo trata simplemente como un infractor. En este sentido, el positivista ético necesita creer que al menos a este nivel, si no antes, hay una radical irreducibilidad de lo político a lo jurídico (que refleja lo que puede llamarse, siguiendo a Christodoulidis, Law and Reflexive Politics, la "reflexividad" de la política). Por lo tanto el positivismo en la versión identificada en este artículo no necesita afirmar que "el derecho en todo caso realiza un valor, pero mientras en su versión extrema éste consiste en un valor final, en la versión moderada consiste en un valor instrumental” (Bobbio, El Problema del Positivismo Jurídico, 46).

${ }^{147}$ Aunque véase Moore, "Law as a Functional Kind”. En todo caso, si el biólogo necesita esa teoría (como sostendría Moore o quienes haya tenido una sobredosis de Kuhn), el argumento del texto principal es más radical: no salva al positivista metodológico, sino hace aplicable la misma conclusión al biólogo. 
La respuesta tiene que ver con el tipo de cosa que el derecho como hecho institucional ${ }^{148} \mathrm{y}$ los organismos vivientes son. Hay un sentido obvio en el que las características de (por ejemplo) la drosophylia son inmunes a las opiniones que el biólogo que la estudia o cualquier otra persona tenga respecto de ella. El biólogo puede entender que la drosophylia es parte de un mundo que no es afectado por sus creencias sobre la drosophylia. Las características (etc) de la drosophylia funcionan, desde el punto de vista del biólogo, como algo que debe ser explicado, es decir, algo que debe ser ubicado en el contexto de una teoría general (de la morfología o genética etc de los insectos, de los organismos vivientes, etc) pero que a la vez sirve de criterio de corrección de esas teorías: las teorías del biólogo intentan explicar una realidad que es independiente de ellas, y son correctas o incorrectas en la medida en que provean explicaciones satisfactorias. La explicación del mundo que está “allá afuera”, como les gusta hiperbolizar a los filósofos autodenominados post-modernos, es lo que constituye el criterio de corrección de las teorías del biólogo. Para justificar su uso del método científico respecto del estudio de la estructura y funcionamiento de los organismos vivientes, en consecuencia, el biólogo sólo necesita creer que esas estructuras y funcionamiento son independientes de cómo nos gustaría a nosotros que fueran.

El problema para el jurista es precisamente que el derecho no es como la drosophylia. La descripción teórica del derecho no deja (como la descripción del biólogo) las cosas tal como estaban, y por consiguiente el científico del derecho no puede entender que el objeto de su estudio es independiente de la descripción que le da. La teoría del derecho re-presenta la práctica jurídica y al hacerlo la reconfigura al menos potencialmente, en el sentido de que si suficientes participantes aceptan esa teoría como la teoría correcta entonces esa teoría será por eso correcta.

En la primera parte de este artículo, al hablar de las disputas domésticas de los auto-denominados positivistas, hemos tenido oportunidad de referirnos a este problema: lo que las teorías entienden como "derecho" es distinto, y por consiguiente lo que la teoría le recomendaría hacer a un juez o abogado o ciudadano que cree que debe cumplir el derecho es distinto. Pero permítaseme volver sobre este problema de una manera ligeramente distinta.

Conforme al artículo 767 del Código de Procedimiento Civil chileno, es posible recurrir en contra de ciertas resoluciones judiciales (típicamente de segunda instancia) de casación en el fondo. La casación en el fondo es un recurso de derecho estricto, que procede respecto de las decisiones de esos

${ }^{148}$ El tema es discutido en el capítulo inicial de Atria, Law and Legal Reasoning. 
tribunales "siempre que se hayan pronunciado con infracción de ley y esta infracción haya influido substancialmente en lo dispositivo de la sentencia”. Si no ha habido infracción de ley, entonces, la sala respectiva de la Corte Suprema no tiene competencia para corregir la decisión del tribunal inferior.

Ahora imaginemos un caso discutible cualquiera, como por ejemplo un caso en el cual durante la negociación de un contrato una de las partes retuvo cierta información que si hubiera sido conocida por la otra habría llevado a que el contrato no se celebrara o que se celebrara en términos sustancialmente distintos. Las partes discuten sobre si la reticencia a comunicar esa información es constitutiva de mala fe, caso en el cual daría origen a responsabilidad por culpa in contrahendo, o es simplemente ejercicio de la libertad de cada parte de velar por sus intereses y no por los de la contraparte. El tribunal de segunda instancia decide que de parte del reticente ha habido mala fe, eligiendo una interpretación discutible pero no absurda del concepto de buena fe, y éste recurre de casación en el fondo.

Una teoría del derecho conforme a la cual en casos de este tipo ("penumbrales”) los jueces tienen discreción en sentido fuerte lleva a la conclusión de que la decisión del tribunal inferior no puede haber sido dictada con infracción de ley, porque no hay nada acerca del derecho que haya podido infringir. La Corte Suprema, por consiguiente, carecería de competencia para revisar esa decisión. Por su parte, una teoría que entiende la labor del intérprete en casos como éste a la manera de la discreción en el sentido débil, por su parte, entendería que es posible que la interpretación del tribunal recurrido haya sido dictada con infracción de ley, y por consiguiente entendería que la Corte Suprema tiene competencia para ver la causa, escuchar los argumentos y decidir en sus méritos acerca de la corrección jurídica de la interpretación del juez recurrido. Para llegar a una conclusión u otra acerca de qué competencia tiene la Corte Suprema nos basta cambiar la descripción teórica. Cuando se trata de prácticas sociales como el derecho, el teórico no puede entender su labor como la descripción de algo que existe con independencia de su descripción, y por eso lo normativo y lo descriptivo están, hasta cierto punto, mezclados.

A partir de este ejemplo la tesis puede ser generalizada. El derecho, después de todo, es un hecho institucional, y los hechos institucionales existen en virtud de las creencias de los participantes en esas instituciones. Las teorías de estos hechos institucionales son retroalimentadas a los participantes, que entonces pueden ajustar sus creencias a las teorías de modo de creer cosas diversas en virtud de ellas. Si nosotros creyéramos, como creían los antiguos romanos, que las formas jurídicas están en el mundo, y que no pueden ser cambiadas sino descubiertas por los seres humanos, y que en consecuencia de lo que se trata es de aprender a manejarlas de la mejor 
manera posible para obtener nuestros fines (como los ingenieros entienden las leyes de la gravedad, que han de ser conocidas y utilizadas para poder construir puentes), entonces nuestro derecho sería un derecho que está en el mundo y que no puede ser modificado ${ }^{149}$. Si nosotros creyéramos, como los abogados del common law, que el derecho es el desenvolvimiento de la razón través de la consideración y decisión de casos a la luz de lo que se ha considerado y decidido en el pasado, entonces para nosotros el derecho sería el desenvolvimiento de la razón a través de la consideración y la decisión de casos particulares a la luz de lo que se ha considerado y decidido en el pasado.

Dicho en breve, el derecho que es depende, hasta cierto punto, de lo que nosotros creamos que el derecho es. Pero a diferencia de las creencias del biólogo sobre la drosophylia, nuestras creencias sobre cómo es el derecho no son (sólo) creencias sobre cómo es el derecho con independencia de nuestras creencias, porque como los hechos institucionales en general el derecho existe porque (colectivamente) creemos que existe. Por lo tanto, nuestras creencias sobre cómo es el derecho (cuál es, por ejemplo, la correcta comprensión de las relaciones entre la constitución chilena y el resto del derecho chileno) son en parte creencias sobre como sería bueno que el derecho fuera. El ciudadano tanto como el jurista formulan y responden estas preguntas, de modo más o menos explícito (éste es el sentido de la famosa afirmación de Dworkin conforme a la cual "la teoría del derecho es la parte general de la adjudicación, el prólogo silencioso de cualquier decisión jurídica" ${ }^{150}$. El jurista que decide que la comprensión correcta del derecho es a-valorativa lo puede hacer creyendo que el derecho es como la drosophylia, existente en el mundo con independencia de nuestras creencias sobre él (lo que sería un caso de falsa conciencia, desde luego) o porque estudiar el derecho desde una perspectiva a-valorativa es la correcta manera de estudiar el derecho, dado el derecho que es (lo que incluye, como hemos visto, nuestras -y sus- creencias sobre cómo sería bueno que el derecho fuera). Por eso la labor del jurista supone una teoría sobre cómo sería bueno que el derecho fuera. Privado de esa teoría lo que hoy denominamos "positivismo jurídico" se hace trivial y estéril, como lo hemos visto y lo seguimos viendo.

\section{Referencias}

ACKerman, B.: Reconstructing American Law (Cambridge, MA: Harvard University Press, 1984).

\footnotetext{
${ }^{149}$ Véase ibíd., 204-222.

${ }^{150}$ Dworkin, Law's Empire, 90 [74].
} 
AlChOuRRón, C. y E. Bulygin: Normative Systems (New York: Reidel, 1971) [Introducción a la Metodología de las Ciencias Jurídicas y Sociales (Buenos Aires: Astrea, 1987; edn. orig. 1971)].

ALEXY, R.: “Derecho injusto, retroactividad y principio de legalidad penal”, en 23 DOXA (2000), pp. 197-230.

Alonso, J.P.: “Un caso difícil en el Código Civil español”, en 17-18 Doxa (1995), pp. 403-432.

ARENDT, H.: On Revolution (Harmondsworth: Penguin, 1977; edn. orig. 1963) [Sobre la Revolución (Madrid: Alianza, 1988; traducido por P. Bravo)].

ATRIA, F.: "Del derecho y del razonamiento jurídico", en 22 Doxa (1999), pp. 79119.

— “El derecho y la contingencia de lo político”, en 26 Doxa (2004), pp. 319-345.

- "Entre jueces y activistas disfrazados de jueces”, en Lagunas en el Derecho. Una controversia sobre el derecho y la función judicial (Madrid: Marcial Pons, 2005), pp. 159-183.

— “Jurisdicción e independencia judicial: el poder judicial como poder nulo", en 5 Revista de Estudios de la Justicia (2005), pp. 119-141.

- “La hora del derecho. Los ‘derechos humanos’ entre el derecho y la política”, en 91 Estudios Públicos (2003), pp. 45-90.

- "La impureza de la aplicación del derecho y sus consecuencias”, en Squella, A (ed.): ¿Qué queda de la Teoría Pura del Derecho? (Valparaíso: EDEVAL, 2005), pp. 157-192.

— On Law and Legal Reasoning (Oxford: Hart Publishers, 2002).

BEATTY, D.: The Ultimate Rule of Law (Madrid: Oxford University Press, 2004).

BenthAM, J.: Bentham to the Citizens of the United States (Edinburgh: William Tait, 1843; edn. orig. 1827).

— Fragment on Government (Edinburgh: William Tait, 1843; edn. orig. 1790).

- Justice and Codification Petitions (Edinburgh: William Tait, 1843; edn. orig. 1827).

— Of Laws in General (London: Athlone Press, 1970).

- Rationale of Judicial Evidence (Edinburgh: William Tait, 1843; edn. orig. 1827).

- Bentham, J: Draught of a Code for the Organization of the Judicial Stablishment in France (Edinburgh: William Tait, 1843; edn. orig. 1790).

BobBio, N.: El Positivismo Jurídico (Madrid: Debate, 1998; edn. orig. 1961; traducido por R. de Asís y A. Greppi).

- El Problema del Positivismo Jurídico (Buenos Aires: EUDEBA, 1965).

BÖHMER, M.: "La corte de los '80 y la corte de los '90: un diálogo sobre el rule of law en Argentina”, en Estado de Derecho y Democracia (Buenos Aires: Editores del Puerto, 2001), pp. 93-118.

CAMPBELL, T.: The Legal Theory of Ethical Positivism (Aldershot: Darmouth, 1996).

Christodoulidis, E.: Law and Reflexive Politics (Dordrecht: Kluwer, 1998).

COKE, E.: Dr Bonham's Case (Indianapolis, IN: Liberty Fund, 2004; edn. orig. 1607). 
— Prohibitions del Roy (Indianapolis, IN: Liberty Fund, 2004; edn. orig. 1607).

Coleman, J.: “Authority and Reason”, en George (ed.): The Autonomy of Law (Oxford: Clarendon Press, 1996), pp. 287-319.

- “Negative and Positive Positivism”, en Cohen, M (ed.): Ronald Dworkin and Contemporary Jurisprudence (Cambridge, MA: Harvard University Press, 1975).

Comanducci, P.: “Formas de neoconstitucionalismo: un análisis metateórico”, en 16 Isonomía (2002), pp. 89-112.

Detmold, M.J.: “Law as Practical Reason”, en 48 Cambridge Law Journal (1989), pp. 436-471.

DwORKIN, R.: “The Forum of Principle”, en A Matter of Principle (Oxford: Clarendon Press, 1985; edn. orig. 1981), pp. 33-71.

— Freedom's Law (Cambridge, MA: Harvard University Press, 1996).

- "Hart's Postscript and the Character of Political Philosophy", en 24 Oxford Journal of Legal Studies (2004), pp. 1-37.

- Law's Empire (London: Fontana, 1986) [El Imperio de la Justicia (Barcelona: Gedisa, 1988; edn. orig. 1986; traducido por C. Ferrari)].

ELY, J.H.: Democracy and Distrust (Cambridge, MA: Harvard University Press, 1980).

EndicotT, T.: "Raz on Gaps: the Surprising Part”, en Meyer, L.H., T. Pogge y S. Paulson (eds): Rights, Culture, and the Law: Themes from the legal and political philosophy of Joseph Raz (Oxford: Oxford University Press, 2003), pp. 99-118.

Ferrajoli: "Pasado y futuro del Estado de derecho", en Carbonell, M. (ed.): Neoconstitucionalismo (s) (Madrid: Trotta, 2003), pp. 13-29.

Fuller, L.: "Positivism and Fidelity to Law - A Reply to Professor Hart”, en 71 Harvard Law Review (1958), pp. 630-672.

GUASTINI, R.: "La constitucionalización del ordenamiento jurídico: el caso italiano”, en Carbonell, M. (ed.): Neoconstitucionalismo (s) (Madrid: Trotta, 2003), pp. 49-73.

HART, H.L.A.: The Concept of Law (Oxford: Clarendon Press, 1994; edn. orig. 1961) [El Concepto de Derecho (Buenos Aires: Abeledo-Perrot, 1963; traducido por G. Carrió)].

- "Demystification of the Law", en Essays on Bentham. Jurisprudence and Political Theory (Oxford: Clarendon Press, 1982).

- “Kelsen's Doctrine of the Unity of Law”, en Essays in Jurisprudence and Philosophy (Oxford: Clarendon Press, 1968), pp. 309-342 ["La teoría de Kelsen sobre la unidad del derecho”, en 21 Boletín Mexicano de Derecho Comparado (1974), pp. 105-140; traducido por R. Tamayo].

- "Positivism and the Separation between Law and Morals", en Essays in Jurisprudence and Philosophy (Oxford: Clarendon Press, 1958), pp. 49-87 [“El positivismo y la independencia entre el derecho y la moral”, en Dworkin, R. (ed): La Filosofía del Derecho (México: Fondo de Cultura Económica, 1980; traducido por J. Sáinz), pp. 35-74].

HobBes, T.: Leviathan (Oxford: Oxford University Press, 1965; edn. orig. 1651) [Leviathan (México: Fondo de Cultura Económica, 1987; traducido por M. Sánchez)]. 
IHERING, R.: El Espíritu del Derecho Romano (Granada: Comares, 1852-1865; edn. orig. 1998).

KeLsen, H.: General Theory of Law and State (Birmingham, Alabama: Legal Classics Library, 1990).

— ¿ ¿Quién debe ser el defensor de la constitución? (Madrid: Tecnos, 1935; traducido por Brie, R.).

Kramer, M.: In Defense of Legal Positivism. Law without Trimmings (Oxford: Clarendon Press, 1999).

LaceY, N.: A Life of H L A Hart. The Nightmare and the Noble Dream (Oxford: Oxford University Press, 2004).

MacInTYRe, A.: After Virtue. A Study in Moral Theory (London: Duckworth, 1985) [Tras la Virtud (Barcelona: Crítica, 1987; traducido por A Varcárcel)].

MARMOR, A.: Positive Law and Objective Values (Oxford: Clarendon Press, 2001).

MiLL, J.S.: Utilitarianism (Oxford: Oxford University Press, 1998; edn. orig. 1863) [El Utilitarismo (Madrid: Alianza, 1984; traducido por E. Guisán)].

Moore, M.: "Law as a Functional Kind", en George (ed.): Natural Law Theory (Oxford: Clarendon Press, 1994; edn. orig. 1994), pp. 188-242.

MoRESo, J.J.: “A Brilliant Disguise. Entre fuentes y lagunas”, en Lagunas en el Derecho. Una controversia sobre el derecho y la función judicial (Madrid: Marcial Pons, 2005).

— “Comanducci sobre neoconstitucionalismo”, en 198 Isonomía (2003), pp. 267282.

— La Teoría del Derecho de Bentham (Barcelona: PPU, 1992).

Moreso, J.J. y J.M. Vilajosana: Introducción a la Teoría del Derecho (Madrid: Marcial Pons, 2004).

MoufFe, C.: El Retorno de lo Político (Madrid: Paidos, 1999).

NAVARro, P.: “Casos difíciles, lagunas en el derecho y discreción judicial”, en Lagunas en el Derecho. Una controversia sobre el derecho y la función judicial (Madrid: Marcial Pons, 2005).

PEndÁs, B.: J. Bentham: política y derecho en los orígenes del estado constitucional (Madrid: Centro de Estudios Constitucionales, 1988).

Pocock, J.A.G.: The Machiavellian Moment, Florentine Political Thought and the Atlantic Republican Tradition (Princeton, NJ: Princeton University Press, 1975).

Postema, G.: Bentham and the Common Law tradition (Oxford: Clarendon Press, 1986).

Pozzolo, S.: "Neoconstitucionalismo y especificidad de la interpretación constitucional”, en Doxa (1998), pp. 339-353.

RADBRUCH, G.: “Arbitrariedad legal y derecho supralegal”, en El Hombre en el Derecho (Buenos Aires: Depalma, 1980; edn. orig. 1946), pp. 127-141.

RAwLS, J.: Political Liberalism (New York, NY: Columbia University Press, 1993) [Liberalismo Político (México: Fondo de Cultura Económica, 1995; traducido por S.R. Madero)].

RAZ, J.: "Authority, Law and Morality", en Ethics in the Public Domain (Oxford: Clarendon Press, 1985), pp. 194-221 [“Autoridad, derecho y moralidad”, en 
La Ética en el Ámbito Público (Barcelona: Gedisa, 2001; traducido por M.L. Melón), pp. 227-257].

- El Concepto de Sistema Jurídico (México: UNAM, 1986; traducido por Tamayo, R.).

- "The Inner Logic of the Law", en Ethics in the Public Domain (Oxford: Clarendon Press, 1994), pp. 222-237 [“La lógica interna del derecho”, en La Ética en el Ámbito Público (Barcelona: Gedisa, 2001)].

- "Legal Reasons, Sources and Gaps”, en The Authority of Law (Oxford: Clarendon Press, 1979), pp. 53-77.

- "Postema on Law's Autonomy and Public Practical Reason: a Critical Comment”, en 4 Legal Theory (1998), pp. 1-20.

- Practical Reason and Norms (Princeton: Princeton University Press, 1992; edn. orig. 1975; traducido por J. Ruiz Manero) [Razón Práctica y Normas (Madrid: Centro de Estudios Constitucionales, 1992; traducido por J. Ruiz Manero)].

RODRÍGUEZ, J.L.: "Imagen actual de las lagunas en el derecho”, en Lagunas en el Derecho. Una controversia sobre el derecho y la función judicial (Madrid: Marcial Pons, 2005).

Schauer, F.: Playing by the Rules (Oxford: Clarendon Press, 1991) [Las Reglas en Juego (Madrid: Marcial Pons, 2004; traducido por C. Orunesu y J.L. Rodríguez)].

SHEPPARD, S. (ed.): The Selected Writings of Sir Edward Coke (Indianapolis, IN: Liberty Fund, 2004).

SMART, J.C.C.: "Extreme and Restricted Utilitarianism”, en P Foot (ed.): Theories of Ethics (Oxford: Oxford University Press, 1967; edn. orig. 1956), pp. 171-183 [“Utilitarismo expremo y restringido”, en P Foot (ed.) Teorías sobre la Ética (México: Fondo de Cultura Económica, 1974; traducido por M. Arbolí), pp. 171-183].

StEIN, P.: Regulae Iuris. From Juristic Rules to Legal Maxims (Edinburgh: Edinburgh University Press, 1966).

von KiRChMAnN, J.H.: La Jurisprudencia no es Ciencia (Madrid: Centro de Estudios Constitucionales, 1983; traducido por A. Truyol y Sierra).

WALDRON, J.: "Custom Redeemed by Statute", en 51 Current Legal Problems (1998), pp. 93-114.

— Law and Disagreement (Oxford: Clarendon Press, 1999).

— “Normative (or Ethical) Legal Positivism”, en Coleman, J (ed.): Hart's Postscript. Essays on the Postscript to The Concept of Law (Oxford: Oxford University Press, 2001).

ZagReBelsKy, G.: El Derecho Dúctil (Madrid: Trotta, 1995; edn. orig. 1995). 
$\triangle \quad$ DOXA 27 (2004) 